\title{
Natural Resources Assessment for the Spallation Neutron Source Second Target Station, Oak Ridge, Tennessee
}

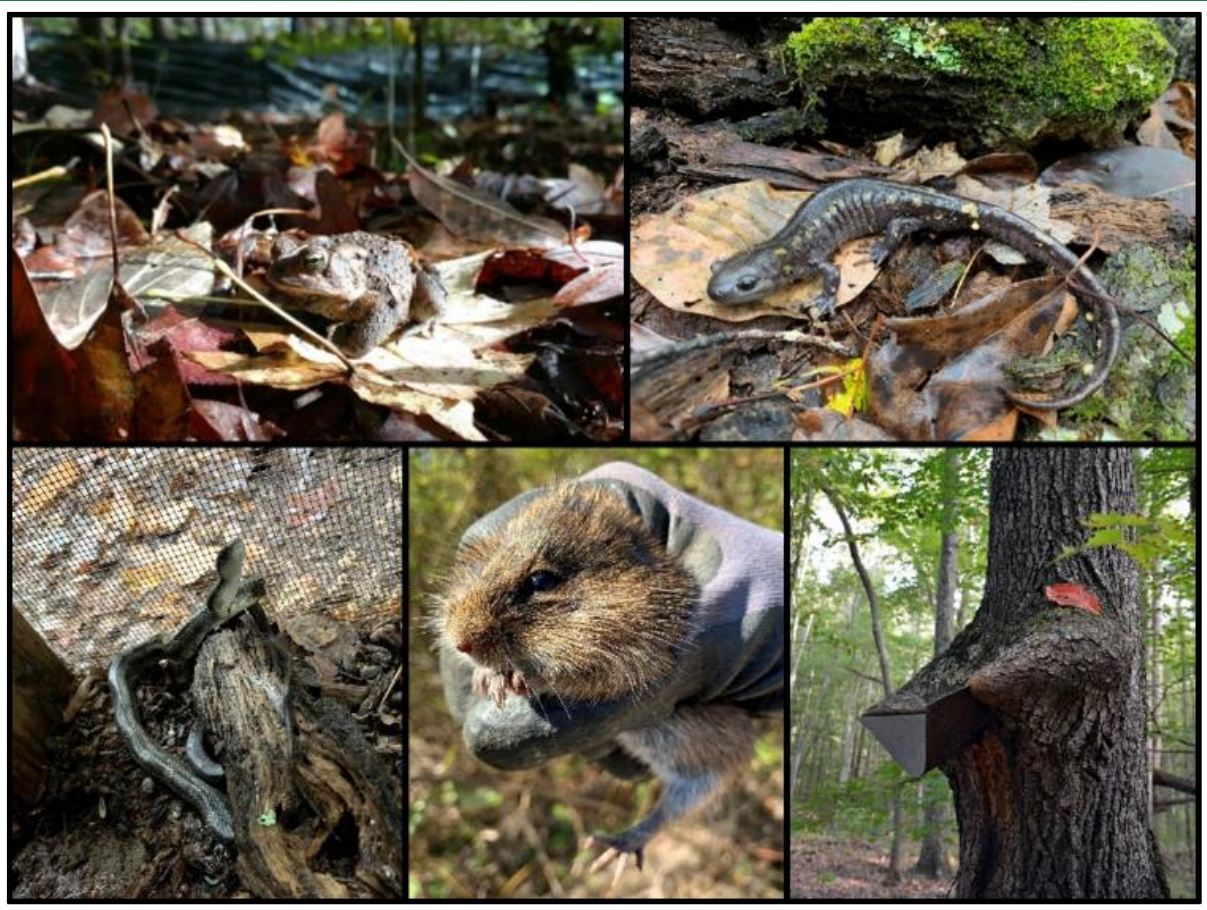

Evin Carter Greg Byrd Kitty McCracken Sara Darling Jamie Herold Lindsey Hayter Bryce Wade Neil Giffen 


\section{DOCUMENT AVAILABILITY}

Reports produced after January 1, 1996, are generally available free via US Department of Energy (DOE) SciTech Connect.

Website www.osti.gov

Reports produced before January 1, 1996, may be purchased by members of the public from the following source:

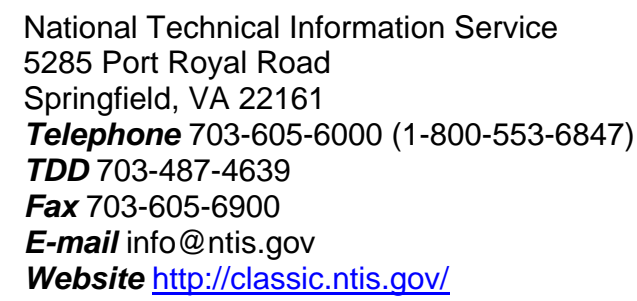

Reports are available to DOE employees, DOE contractors, Energy Technology Data Exchange representatives, and International Nuclear Information System representatives from the following source:

Office of Scientific and Technical Information

PO Box 62

Oak Ridge, TN 37831

Telephone 865-576-8401

Fax 865-576-5728

E-mail reports@osti.gov

Website http://www.osti.gov/contact.html

This report was prepared as an account of work sponsored by an agency of the United States Government. Neither the United States Government nor any agency thereof, nor any of their employees, makes any warranty, express or implied, or assumes any legal liability or responsibility for the accuracy, completeness, or usefulness of any information, apparatus, product, or process disclosed, or represents that its use would not infringe privately owned rights. Reference herein to any specific commercial product, process, or service by trade name, trademark, manufacturer, or otherwise, does not necessarily constitute or imply its endorsement, recommendation, or favoring by the United States Government or any agency thereof. The views and opinions of authors expressed herein do not necessarily state or reflect those of the United States Government or any agency thereof. 
Natural Resources Management Program

\title{
NATURAL RESOURCES ASSESSMENT FOR THE SPALLATION NEUTRON SOURCE SECOND TARGET STATION, OAK RIDGE, TENNESSEE
}

\author{
Evin Carter $^{1}$ \\ Greg Byrd ${ }^{2}$ \\ Kitty McCracken ${ }^{1}$ \\ Sara Darling ${ }^{2}$ \\ Jamie Herold ${ }^{2}$ \\ Lindsey Hayter ${ }^{2}$ \\ Bryce Wade ${ }^{1}$ \\ Neil Giffen ${ }^{2}$
}

${ }^{1}$ Environmental Sciences Division

${ }^{2}$ Facilities and Operations Directorate

Natural Resources Management Program

Oak Ridge National Laboratory

Prepared for

Second Target Station Project Office

Oak Ridge National Laboratory

Prepared by

OAK RIDGE NATIONAL LABORATORY

Oak Ridge, TN 37831-6283

managed by

UT-BATTELLE, LLC

for the

US DEPARTMENT OF ENERGY

under contract DE-AC05-00OR22725 



\section{CONTENTS}

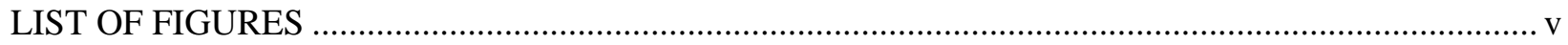

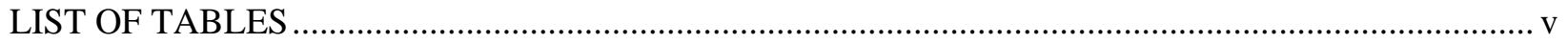

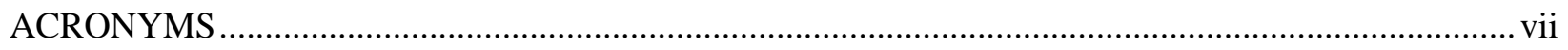

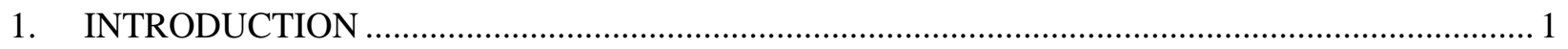

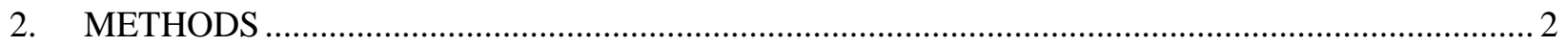

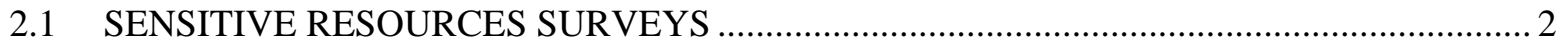

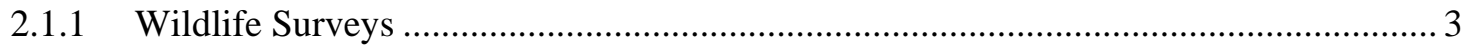

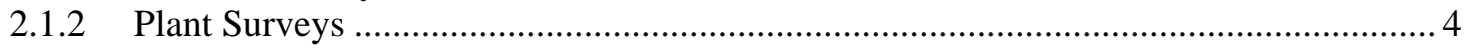

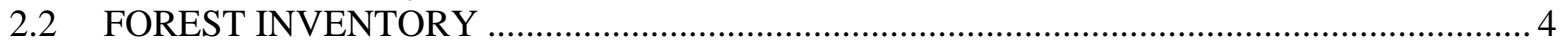

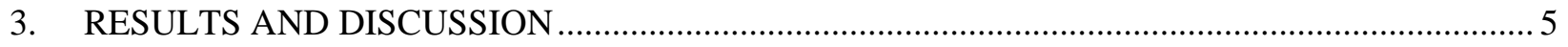

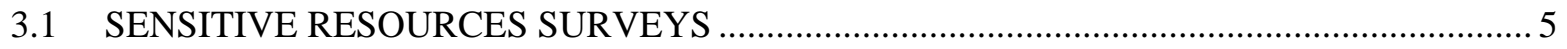

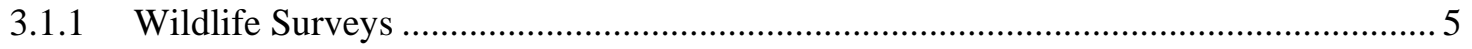

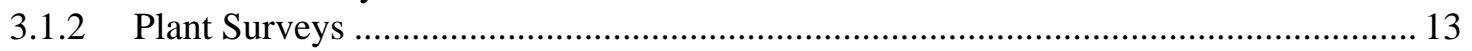

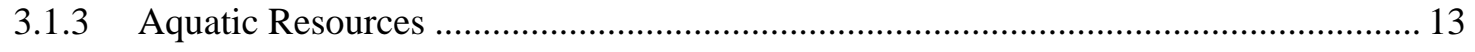

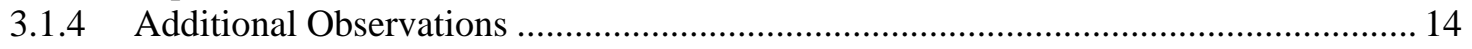

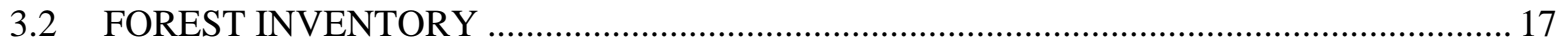

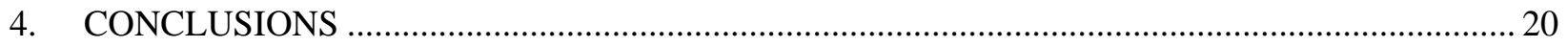

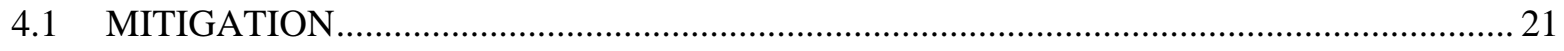

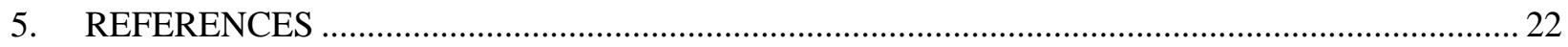

APPENDIX I. METHODS AND RESULTS FOR 2009 SURVEYS …................................................

APPENDIX II. ADDITIONAL DETAILS FROM 2013 FOREST INVENTORY …........................... II-1

APPENDIX III. COMPLETE LIST OF VERTEBRATE SPECIES DOCUMENTED WITHIN

THE SNS STS PROJECT AREA ............................................................................................. 



\section{LIST OF FIGURES}

Figure 1. Review area for the proposed STS on DOE's ORR, Oak Ridge, Tennessee. ............................2

Figure 2. Natural resources survey areas for the SNS STS project (dashed red border). ......................... 3

Figure 3. (left) Sara Darling measuring and tagging a copperhead after checking drift fence arrays within the northcentral portion of the STS survey area; (right) following installation of a

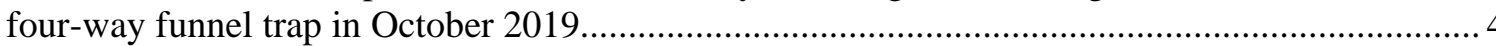

Figure 4. Contemporary and historical forest bat resources. ............................................................... 8

Figure 5. State-listed four-toed salamander and wetland breeding habitat at the southernmost end of the STS review area.

Figure 6. Representative images of reptile remains found in erosion netting during surveys along Perimeter Road in the northeastern portion of the survey area................................................... 10

Figure 7. Examples of wildlife encountered during 2019 field surveys. ............................................... 11

Figure 8. Species accumulation curves based on funnel trap captures of invertebrates (red) and small vertebrates (blue) from fall 2019 to summer 2020.

Figure 9. Aquatic resources within the STS review and project area (solid and dashed magenta line, respectively).

Figure 10. Status species locations, excluding birds. All bat points represent at least one federally listed species.

Figure 11. Forest cover and land use within the STS project area based on 2013 forest inventory data......

Figure 12. Historic and cultural resources within the survey area.

Figure 13. Example of the type of double apron obstacle found within the survey area near Building 0907 (Katy's Kitchen).

\section{LIST OF TABLES}

Table 1a. Results from acoustic bat detectors from October 15 to 29, 2019........................................... 6

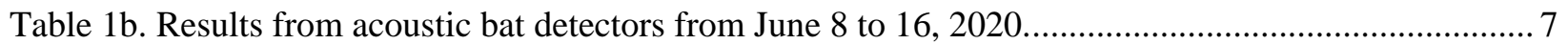

Table 2. Status wildlife species present within the SNS STS project area based on historical (pre1995) and contemporary observation (1995 to present).

Table 3. List of 36 tree species inventoried within the STS survey area. 


\section{ACRONYMS}

$\begin{array}{ll}\text { BCC } & \text { USFWS bird of conservation concern } \\ \text { BMC } & \text { USFWS bird of management concern } \\ \text { dbh } & \text { diameter at breast height }(4.5 \mathrm{ft}) \\ \text { DOE } & \text { US Department of Energy } \\ \text { GPS } & \text { global positioning system } \\ \text { MBTA } & \text { Migratory Bird Treaty Act } \\ \text { ORNL } & \text { Oak Ridge National Laboratory } \\ \text { ORR } & \text { Oak Ridge Reservation } \\ \text { PIF } & \text { Partners in Flight } \\ \text { SNS } & \text { Spallation Neutron Source } \\ \text { STS } & \text { Second Target Station } \\ \text { TDEC } & \text { Tennessee Department of Environment and Conservation } \\ \text { TWRA } & \text { Tennessee Wildlife Resources Agency } \\ \text { USFWS } & \text { US Fish and Wildlife Service } \\ \text { VES } & \text { visual encounter survey }\end{array}$





\section{INTRODUCTION}

The US Department of Energy's Oak Ridge National Laboratory (ORNL) is a leading institution in advanced materials, supercomputing, neutrons, and nuclear science. As a research laboratory managed by UT-Battelle, LLC for DOE, ORNL has national priorities in energy, security, and scientific discovery that necessitate facility improvements and expansions. DOE is also committed to environmental stewardship. The laboratory is located on the $\sim 32,000$-acre Oak Ridge Reservation (ORR), much of which is categorized as a National Environmental Research Park and a state Wildlife Management Area. DOE works with the Tennessee Wildlife Resources Agency (TWRA), Tennessee Department of Environment and Conservation (TDEC), US Fish and Wildlife Service (USFWS), US Department of Agriculture, and other agencies to serve as an effective steward of the ORR. Accordingly, project managers must conform to environmental regulations, agreements, and policies at the federal, state, and institutional levels. Per 40 CFR (Code of Federal Regulations) 1508.14, potential effects on research and science education on the National Environmental Research Park represent potential impacts of federal actions. Moreover, federal actions that affect the quantity and quality of hunting opportunities and deer reduction harvest on the Oak Ridge Wildlife Management Area must be considered whenever other aspects of the human environment (as defined by NEPA) are affected.

The Spallation Neutron Source (SNS) is a premiere facility at ORNL that provides advanced capabilities in neutron scattering to promote new discoveries and research opportunities in material sciences, physics, chemistry, biological sciences, and others. A conceptual design for a Second Target Station (STS) has been in consideration for several years. The STS is intended to complement and enhance existing ORNL capabilities, notably research and exploration of complex materials. The proposed STS will involve development of existing natural areas on the ORR, which might contain sensitive resources that require mitigation or avoidance in accordance with existing policies and regulation.

This report summarizes current knowledge of natural and cultural resources within the STS project area. At the time of this report, the proposed STS project consisted of an operations area comprising 55.4 acres (22.4 ha) and a total review area for potential construction comprising $\sim 224$ acres (90.6 ha). The review area is located primarily within forested natural areas of the ORR with minor development in the form of power-line rights-of-way and secondary/graveled roads (Figure 1). The primary goal was to evaluate potential effects on sensitive resources that might result from development of the STS. In addition to onthe-ground surveys during summer 2009 and fall 2019 to summer 2020 by ORNL Natural Resources Management Program and Aquatic Ecology Group staff, this report makes use of historical (pre-1995) and contemporary (1995 to present) data from additional confirmed sources (e.g., TDEC). Likewise, forest conditions were compiled primarily from a 2013 forest inventory effort for Forest Management Compartment 17 and supplemented with limited ground observations in 2019. The individuals who obtained and compiled the data that are presented here are familiar with and routinely assess sensitive resources on the ORR.

Biological surveys rarely permit a full picture of the resources that will be affected. Additional species are expected to be present at low detection frequency. Moreover, natural area loss within relatively small areas of the ORR can have meaningful effects on ecosystem and human health even beyond the ORR. We attempt to consider these uncertainties herein. Accordingly, this report should facilitate environmentally sound decisions during planning and development of the STS and help project managers address regulatory guidance and DOE policy as it relates to sustainable development in compliance with, for example, the US Endangered Species Act, Migratory Bird Treaty Act (MBTA), Tennessee Rare Plant Protection and Conservation Act of 1985, Tennessee Nongame and Endangered or Threatened Wildlife Species Conservation Act of 1974, several federal and state regulations regarding aquatic resource 
protection, and site-specific policies as outlined in various ORR management plans developed by ORNL and TWRA for DOE (e.g., Carter et al. 2020).

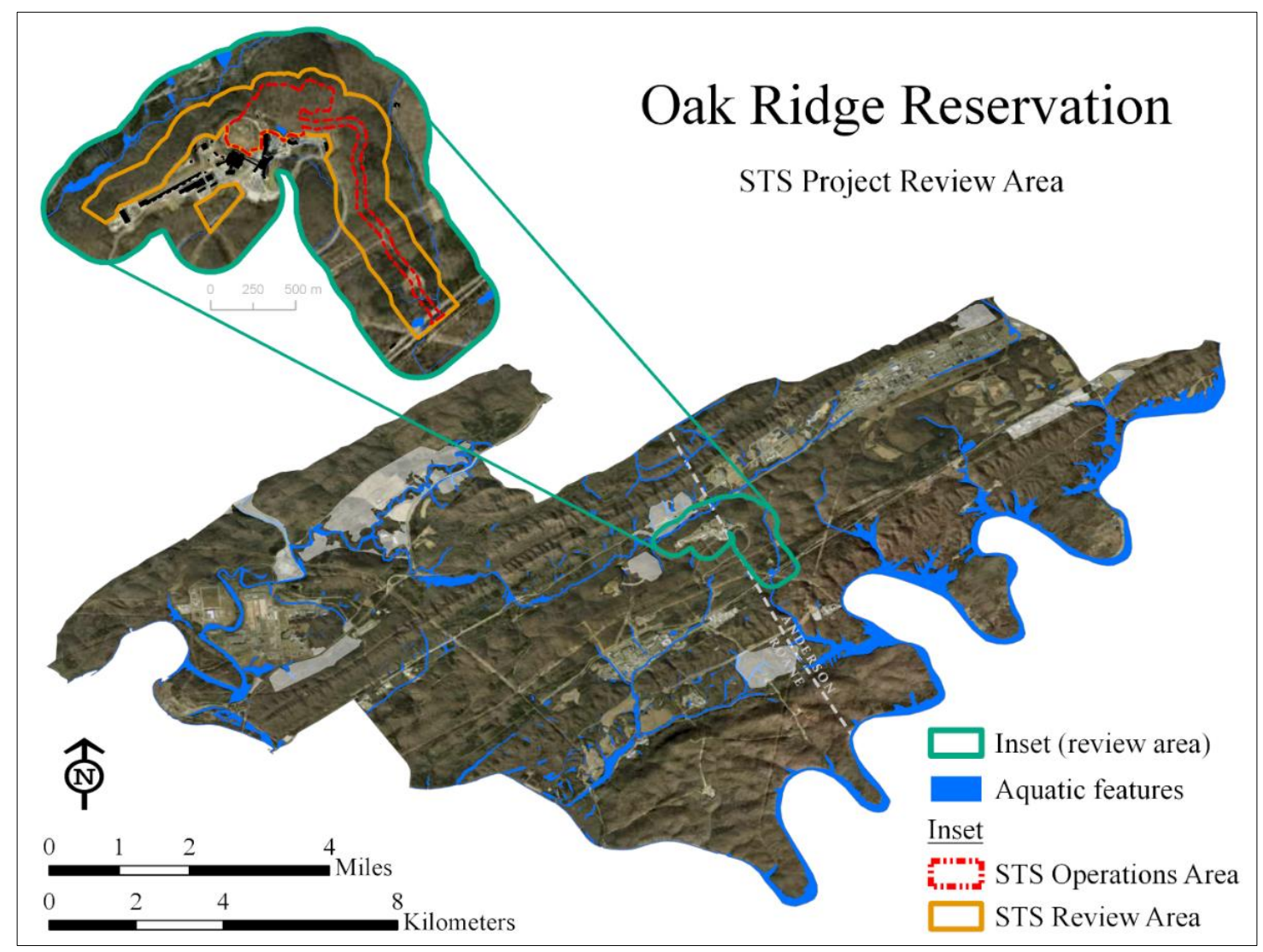

Figure 1. Review area for the proposed STS on DOE's ORR, Oak Ridge, Tennessee.

\section{METHODS}

Overview - In addition to two on-the-ground surveys in 2009 and 2019 to 2020, the authors compiled historical (pre-1995) and contemporary (1995 to present) data on sensitive resources within the STS review area from (1) previous reports and observations by ORNL Natural Resources, (2) reports made available to ORNL Natural Resources by researchers and contractors on the ORR (e.g., 2013 Forest Inventory), and (3) the TDEC's Natural Heritage Inventory Program. Historical observations (pre-1995) are especially relevant to quantify rare species, which are inherently difficult to detect. Thus, historical observations were presumed valid unless subsequent targeted surveys failed to detect those resources, and/or - in the case of sensitive flora and fauna — other resources that are critical to their persistence were no longer present or adequate.

\subsection{SENSITIVE RESOURCES SURVEYS}

Environmental surveys for much of the STS survey area were first conducted in 2009 for what was then termed the "SNS Target Building \#2" (Giffen et al. 2009). The 2009 survey area did not include the planned access road that will link Bethel Valley Road to the STS. Methods and results from the 2009 report are in Appendix I, along with more detailed plant surveys compared with those conducted in 2019. New sensitive resources surveys within the STS project area (Figure 2) occurred from September 17 to October 31, 2019 and March 26 to August 10, 2020. 


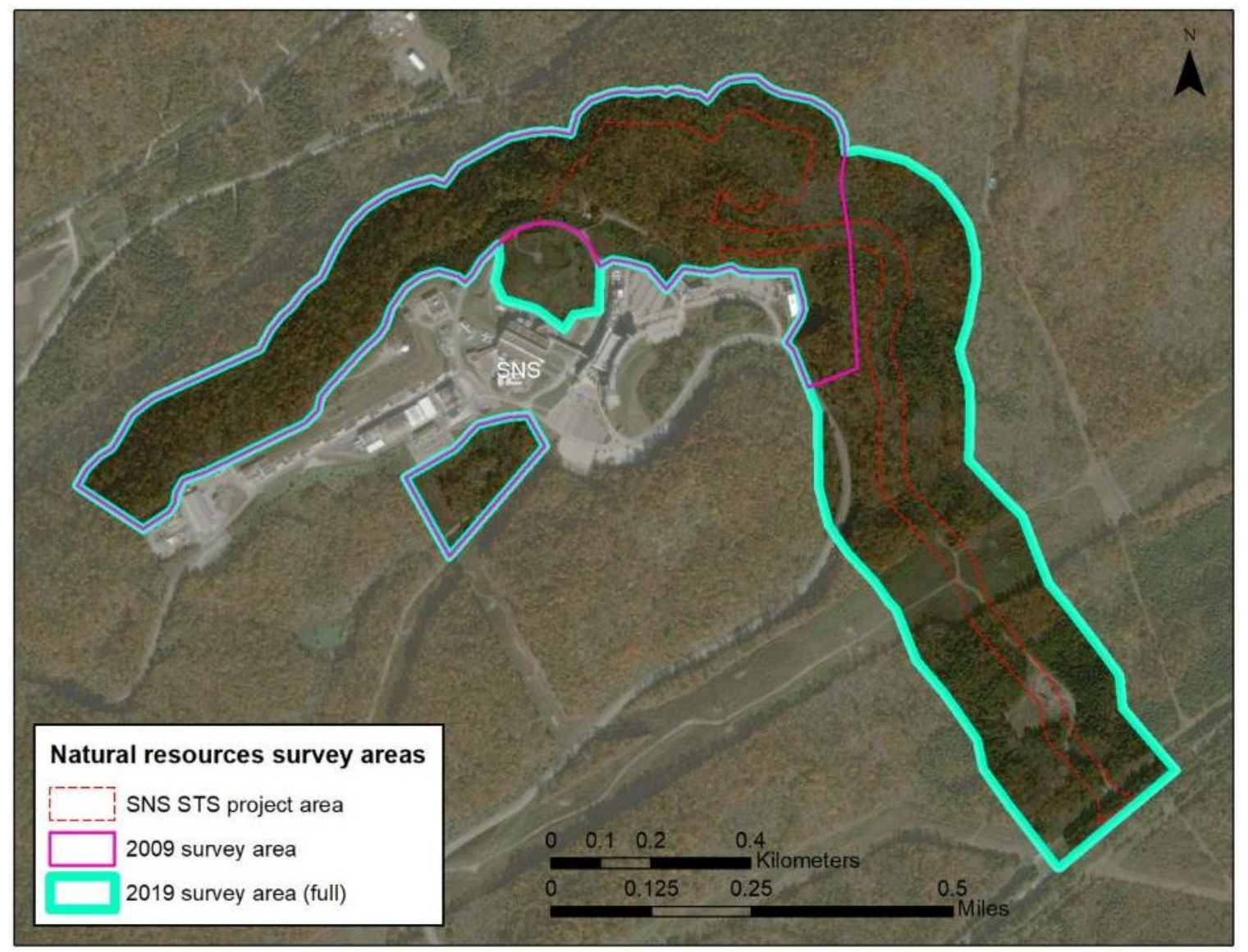

Figure 2. Natural resources survey areas for the SNS STS project (dashed red border). The 2009 survey area was expanded in October 2019 to account for the access road that connects to Bethel Valley Road.

\subsubsection{Wildlife Surveys}

Bat acoustic surveys - Five bat acoustic monitors (Wildlife Acoustics Song Meter SM4Bat FS Ultrasonic Recorders equipped with SMM-U2) were positioned in likely flyways and foraging zones throughout the survey area from October 15-29 and June 8-16, 2020. Sites for acoustic recording were selected based on likelihood of use by bats as flyways to foraging grounds and/or for foraging. Microphones were mounted on 3-m poles and directed along the likely flyway. Recording began $30 \mathrm{~min}$ before sunset and ended 30 min after sunrise each night. All SM4Bat monitors were deployed for 14 consecutive nights, beginning October 15, 2019. Data were collected and analyzed using Kaleidoscope Pro Analysis Software, version 5 with both zero-crossing and full-spectrum analysis methods, as approved by the USFWS.

Reptiles and amphibian visual encounter surveys (VESs)—We implemented VESs along two primary transects throughout the extent of the study area and once each along all forest edges and roadsides. Previously installed erosion netting along the northern perimeter of SNS was also surveyed opportunistically throughout the 2019 and 2020 field seasons to detect ensnared reptiles or their carcasses.

Small mammal trapping - To quantify small mammal abundance and diversity, 144 ( $\mathrm{n}=57$ in the fall; $\mathrm{n}=87$ in the spring) Sherman live traps were positioned every 30 to $60 \mathrm{~m}$ along a transect that extended north from Bethel Valley Road, along the planned STS access road, and west through the primary impact area. Separate Sherman live trap arrays were also placed around a retention pond $(n=3)$ and a high grassy field $(n=10)$ located in the northeast portion of SNS, south of Perimeter Road in the fall of 2019. 
Eighty-seven Sherman traps were placed in the southern portion of the project area during the spring. Traps were placed primarily in the southern portion of the project area in the moist forest habitat just north of Old Bethel Valley Road.

Bird point counts - Avian point counts were implemented at each of the small mammal trap sites and at 10 additional locations throughout the survey area. All bird species seen or heard within a period of 10 min were recorded. Each site was visited 10 times throughout October 2019, twice from September 1726, 2019, and 10 times during April 2020.

Drift fence surveys (small vertebrates) — A drift fence array was installed to provide a detailed assessment of small vertebrates within the central portion of the survey area, where most new development is being considered. The drift fence array consisted of $\sim 200$ in. of silt fence installed in an " $x$ " pattern with a fourway funnel trap at its center (Figure 3). A single funnel trap was also positioned at the terminus of each of the four silt fences. Traps were checked daily when active (Monday through Friday each week), and bird seed, shelter, and a water source were provided within each trap. In total, the trap was active for $\sim 120$ days and nights from 17 September-31 October 2019 and 26 March-10 August 2020.
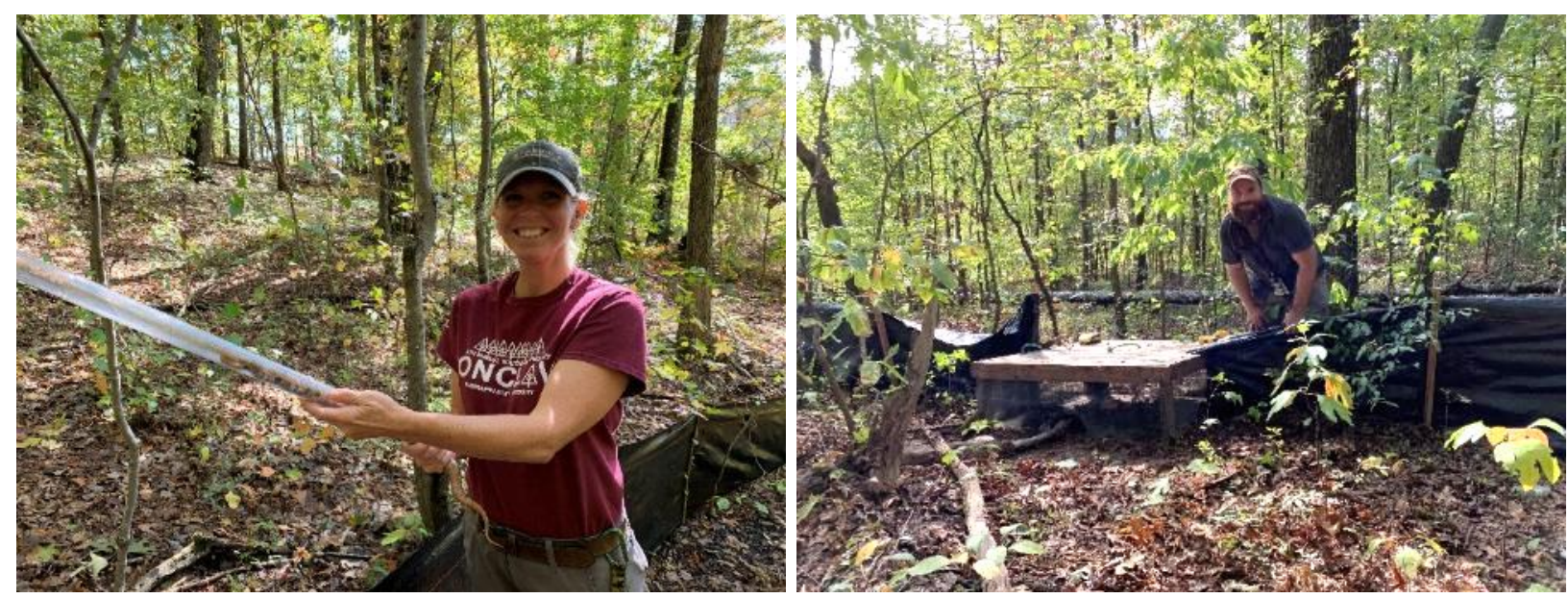

Figure 3. (left) Measuring and tagging a copperhead after checking drift fence arrays within the northcentral portion of the STS survey area; (right) following installation of a four-way funnel trap in October 2019.

\subsubsection{Plant Surveys}

Rare plant surveys were conducted primarily to confirm detailed assessment in 2009. Walkdowns were conducted along similar transects to those established in 2009 (Appendix I, Figure 1) as well as the planned access road that will connect the STS facilities to Bethel Valley Road (Figures 1 and 2).

\subsection{FOREST INVENTORY}

Forest conditions were assessed based on a forest inventory conducted in 2013 and on current ground observations. A forest inventory for Forest Management Compartment 17, which contains the SNS STS survey area, was concluded in November 2013 (Johnston, unpublished report to the ORNL Natural Resources Management Program). More than 470 sampling points were taken on a 300 by $300 \mathrm{ft}$ grid covering the 970-acre (393-ha) compartment. A subset of 103 points fell within the STS survey area and were extracted for this review (Appendix II). 


\section{RESULTS AND DISCUSSION}

\subsection{SENSITIVE RESOURCES SURVEYS}

\subsubsection{Wildlife Surveys}

All wildlife known from the STS review area are included in Appendix III, alongside their state and federal protection status. In total, 151 vertebrate and invertebrate wildlife taxa are known from the review area (Appendix III). Of all species known from the STS review area, at least 10 are afforded special legal protection under state or federal law, 5 species are considered by USFWS to be both birds of conservation concern (BCC) and birds of management concern (BMC), 2 species are BCC-only, and 2 species are BMC-only (in addition to $\geq 50$ bird species afforded protection under the MBTA [16 U.S.C. $\S \S 703-711]$ ). Additionally, at least one species is considered rare by TDEC, and seven species represent ORNL focal species for management and research (imperiled bats and four-toed salamander) (Appendix III).

Bat acoustic surveys - Results from five bat acoustic detectors deployed from 15-29 October 2019 (70 survey nights during fall swarming season) are included in Table 1a. Table $1 \mathrm{~b}$ results are from six bat acoustic detectors deployed from 8-16 June 2020 (63 survey nights during summer roosting season). In total, 15 native bat species were detected. Detection frequencies provide strong evidence for 10 species, reasonable evidence for 4 species, and 1 species was considered unlikely within the STS survey area. Both state and federally listed species - including federally endangered gray bats (Myotis grisescens), state threatened little brown bats (Myotis lucifugus), and state threatened tricolored bats (Perimyotis subflavus) (also under federal review) - were detected at high frequency. Four additional species with state and/or federal listing status were considered probable residents given either moderate detection frequency or incidental observation (Tables $1 \mathrm{a}$ and $1 \mathrm{~b}$ ). Habitat suitable to each bat species was abundant throughout the project area but particularly within the open and mature forest in the northcentral portion of the STS project area (Figure 4). 
Table 1a. Results from acoustic bat detectors from 15-29 October 2019. The number of call detections is included for each detector. A low number of detections, within and between monitors, is considered poor evidence of presence. Shaded rows represent status species. Darker shading indicates greater confidence based on the number of calls, suitable habitat, and nearby location records. (SR: considered rare or regionally important by the state of Tennessee; SD: state deemed in need of management; ST: state threatened; SE: state endangered; FT: federally threatened; FE: federally endangered; FP: federal listing petition currently under review).

\begin{tabular}{lcccccccc}
\hline \multirow{2}{*}{ Species } & \multirow{2}{*}{ Species code } & \multicolumn{4}{c}{ Bat detector site } & Considered & \multirow{2}{*}{ Status } \\
\cline { 3 - 7 } present & 1-19 & $\mathbf{2 - 1 9}$ & $\mathbf{3 - 1 9}$ & $\mathbf{4 - 1 9}$ & $\mathbf{5 - 1 9}$ & & \\
\hline Corynorhinus rafinesquii & CORA & 0 & 3 & 4 & 0 & 0 & Probable & SD \\
Eptesicus fuscus & EPFU & 5 & 3 & 1 & 0 & 8 & Yes & \\
Lasiurus borealis & LABO & 6 & 3 & 51 & 86 & 191 & Yes & \\
Lasiurus cinereus & LACI & 77 & 34 & 23 & 0 & 15 & Yes & \\
Lasionycteris noctivagans & LANO & 41 & 14 & 15 & 0 & 137 & Yes & \\
Myotis austroriparius & MYAU & 0 & 0 & 0 & 0 & 1 & Unlikely & SR \\
Myotis grisescens & MYGR & 12 & 28 & 59 & 21 & 394 & Yes & FE, SE \\
Myotis leibii & MYLE & 1 & 2 & 1 & 0 & 2 & Probable & SD \\
Myotis lucifugus & MYLU & 3 & 9 & 13 & 3 & 58 & Yes & ST \\
Myotis septentrionalis & MYSE & 0 & 1 & 2 & 0 & 0 & Probable & FT, ST \\
Myotis sodalis & MYSO & 0 & 3 & 3 & 0 & 1 & Probable & FE, SE \\
Nycticeius humeralis & NYHU & 2 & 0 & 28 & 13 & 280 & Yes & \\
Perimyotis subflavus & PESU & 5 & 0 & 11 & 24 & 378 & Yes & FP, ST \\
Tadarida brasiliensis & TABR & 30 & 10 & 3 & 0 & 9 & Yes & \\
Lasiurus seminolus & LASE & 0 & 0 & 0 & 0 & 197 & Yes & \\
\hline
\end{tabular}


Table 1b. Results from acoustic bat detectors from 8-16 June 2020. The number of call detections is included for each detector.

\begin{tabular}{|c|c|c|c|c|c|c|c|c|c|}
\hline \multirow{2}{*}{ Species } & \multirow{2}{*}{$\begin{array}{l}\text { Species } \\
\text { code }\end{array}$} & \multicolumn{6}{|c|}{ Bat detector site } & \multirow{2}{*}{$\begin{array}{l}\text { Considered } \\
\text { present }\end{array}$} & \multirow{2}{*}{ Status } \\
\hline & & $1-20$ & $2-20$ & 3-20 & 4-20 & $5-20$ & 6-20 & & \\
\hline $\begin{array}{l}\text { Corynorhinus } \\
\text { rafinesquii }\end{array}$ & CORA & 0 & 0 & 0 & 0 & 0 & 1 & Possible & SD \\
\hline Eptesicus fuscus & EPFU & 0 & 1 & 0 & 0 & 0 & 393 & Yes & \\
\hline Lasiurus borealis & LABO & 90 & 25 & 109 & 1 & 0 & 692 & Yes & \\
\hline $\begin{array}{l}\text { Lasiurus } \\
\text { cinereus }\end{array}$ & LACI & 1 & 28 & 0 & 201 & 0 & 0 & Yes & \\
\hline $\begin{array}{l}\text { Lasionycteris } \\
\text { noctivagans }\end{array}$ & LANO & 2 & 4 & 3 & 1 & 0 & 0 & Yes & \\
\hline $\begin{array}{l}\text { Myotis } \\
\text { austroriparius }\end{array}$ & MYAU & 0 & 0 & 0 & 0 & 0 & 0 & Unlikely & SR \\
\hline $\begin{array}{l}\text { Myotis } \\
\text { grisescens }\end{array}$ & MYGR & 184 & 2 & 0 & 1 & 5 & 46 & Yes & $\mathrm{FE}, \mathrm{SE}$ \\
\hline Myotis leibii & MYLE & 0 & 0 & 0 & 0 & 0 & 0 & Possible & SD \\
\hline Myotis lucifugus & MYLU & 152 & 89 & 38 & 1 & 0 & 68 & Yes & $\mathrm{ST}$ \\
\hline $\begin{array}{l}\text { Myotis } \\
\text { septentrionalis }\end{array}$ & MYSE & 0 & 0 & 0 & 0 & 0 & 0 & Possible & FT, ST \\
\hline Myotis sodalis & MYSO & 18 & 2 & 1 & 0 & 0 & 0 & Probable & $\mathrm{FE}, \mathrm{SE}$ \\
\hline $\begin{array}{l}\text { Nycticeius } \\
\text { humeralis }\end{array}$ & NYHU & 0 & 0 & 0 & 1 & 0 & 3 & Possible & \\
\hline $\begin{array}{l}\text { Perimyotis } \\
\text { subflavus }\end{array}$ & PESU & 0 & 2 & 9 & 3 & 0 & 190 & Yes & FP, ST \\
\hline $\begin{array}{l}\text { Tadarida } \\
\text { brasiliensis }\end{array}$ & TABR & 2 & 0 & 2 & 2 & 0 & 3 & Yes & \\
\hline $\begin{array}{l}\text { Lasiurus } \\
\text { seminolus }\end{array}$ & LASE & 0 & 1 & 2 & 2 & 0 & 3 & Yes & \\
\hline
\end{tabular}




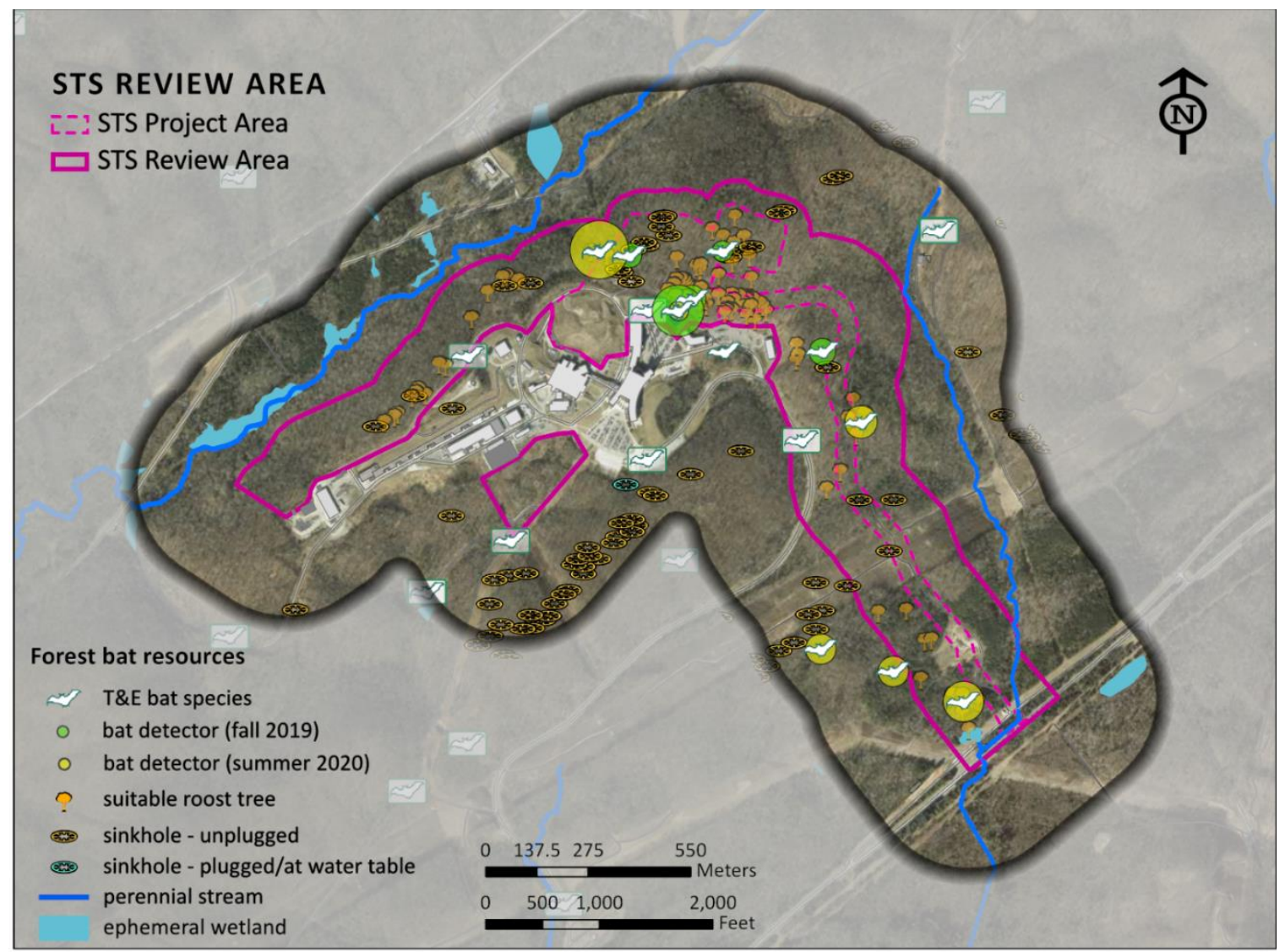

Figure 4. Contemporary and historical forest bat resources. All known locations within the vicinity of SNS with records for threatened and endangered bat species are included (see also Table 1a and 1b). Green circles depict bat detector locations from fall $2019(\mathrm{n}=5)$; yellow circles represent bat detector locations from summer 2020

$(n=5)$. Each circle is sized relative to the number of bats detected at that location. Roost trees (orange) are based on 2009 and 2019 to 2020 surveys and are largely represented by white oak.

Bird point counts (13 person-hours) - In total, 60 bird species were identified from approximately 22 survey hours (13 $\mathrm{h}$ in 2019, $9 \mathrm{~h}$ in 2020). This included 59 species protected under the MBTA, including 4 species considered to be BMCs, 4 species considered by Partners in Flight (PIF) to be species in steep decline, and 1 species considered by TDEC to be rare in the state of Tennessee (Table 2). No other stateor federally listed bird species were detected, although TDEC data indicate the historical occurrence of peregrine falcon (Falco peregrinus) along the planned access road near Bethel Valley Road. This species is no longer listed by the state of Tennessee but also falls under the protection of the MBTA (Table 2).

Small mammal trapping (1270 total trap nights) —No status small mammal species were detected during summer/fall of 2019 or spring/summer of 2020. Common species included deer mice (Peromyscus spp), cotton rats (Sigmodon hispidus), chipmunks (Tamias striatus), house mice (Mus musculus), and shorttailed shrews (Blarina brevicauda).

Historical data from ORNL and TDEC indicate the presence of southern bog lemmings (Synaptomys cooperi) throughout the southernmost portion of the survey area near Bethel Valley Road. This species is listed as "in need of management" by both TWRA and TDEC. Focused trapping efforts in the southern portion of the project area during spring 2020 failed to detect any specimens. Its presence remains possible, but dense invasive plant cover and repeated mowing through the wetland have compromised habitat. Given that prior presence indicates a high potential for bog lemmings in the area, invasive plant 
removal and wetland/grassland restoration in this area might serve to offset some impacts of STS construction and qualify as mitigation at the state level.

Reptile and amphibian surveys (visual encounter and cover boards) (45 person-hours)—We observed 18 amphibian and reptile species during visual encounter and cover board surveys. These included six species not detected via funnel traps (see Drift fence surveys below): ringnecked snake (Diadophis punctatus), watersnake (Nerodia sipedon), earthsnake (Virginia valeriae), Cope's gray treefrog (Hyla chrysoscelis), four-toed salamander (Hemidactylium scutatum), and chorus frog (Pseudacris feriarum).

Previous surveys indicated the presence of four-toed salamanders (Hemidactylium scutatum) within the survey area, north of SNS. Although the atypical habitat in which one individual was found suggested that the salamander was transient (Giffen et al. 2009), potentially suitable breeding habitat for four-toed salamanders was documented in the northeastern portion of the area during 2019 surveys. No specimens were found in this area during the spring 2020 reproductive season, but a large breeding population of four-toed salamander was identified in the wetland and moist forest in the southernmost portion of the STS footprint, where bog lemmings were historically known to occur (Figure 5). Along with the bog lemming, this species is listed as "in need of management" by the state of Tennessee. Detectability is extremely low outside of the spring breeding season, thus additional survey of suitable habitat during spring 2020 was necessary to confirm presence, and the extent of occurrence of this state-listed species within the STS footprint might be larger than is currently known. The ORNL Aquatic Ecology Group and Natural Resources Management have made considerable efforts in identifying four-toed salamander populations and important corridors for movement by this sensitive species on the ORR. Recent field and ecological modeling studies have identified the forest surrounding SNS as important to four-toed salamander movement (Wade and Carter 2020; Wade, DeRolph, and Carter 2020). This would explain why previous surveys recorded this species as likely transient in atypical habitat within the STS review area. The STS project area appears to represent a considerable corridor between populations in Bear Creek Valley and within the Bearden Creek and Melton Branch watersheds (Wade and Carter 2020).

The remains of 17 individual reptiles were identified within erosion netting along Perimeter Road (Figure 6). Of these individuals, four species were identified with confidence, which included ratsnakes (Pantherophis spiloides), eastern racers (Coluber constrictor), gartersnakes (Thamnophis sirtalis) and copperheads (Agkistrodon contortrix). The remains of one individual could not be positively identified. However, osteological features of the skull and teeth suggest that it was an eastern slender glass lizard (Ophisaurus attentuatus). This species is listed as "in need of management" by the state of Tennessee, but its presence cannot be confirmed without additional survey. Suitable habitat exists along road edges surrounding SNS. However, the extensive erosion netting and previous construction of the SNS facility has likely eliminated the primary useable habitat for this species on the ORR.

Additional species encountered during visual surveys or as incidentals can be found in Appendix III and several representatives are shown in Figure 7 (including drift fence array captures). 


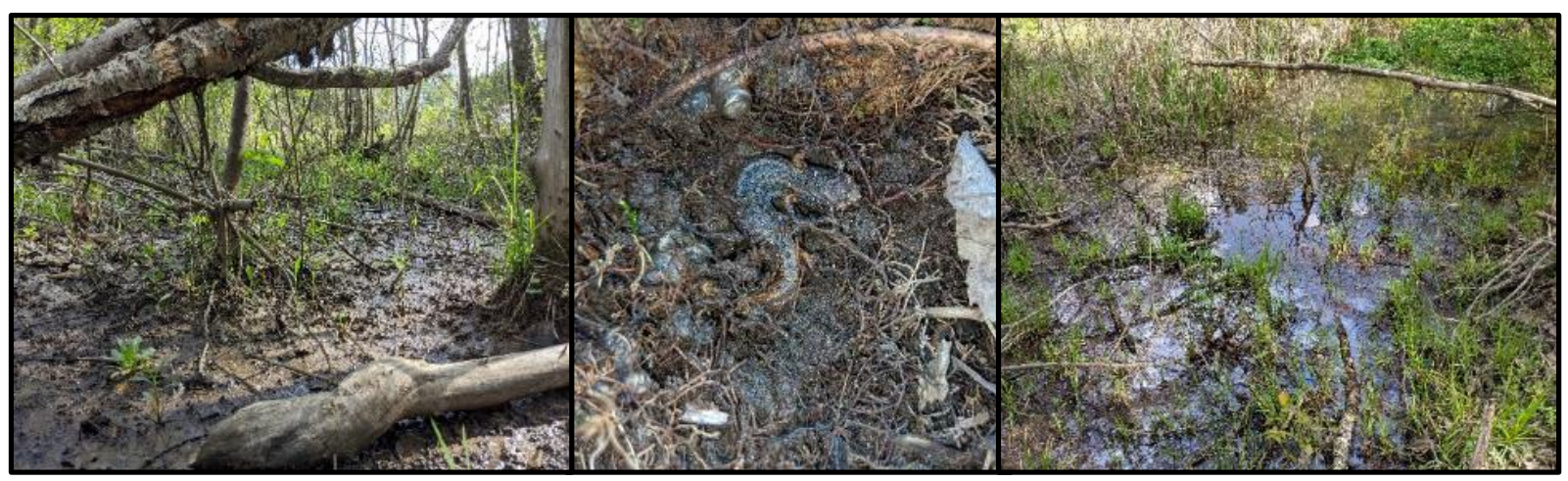

Figure 5. State-listed four-toed salamander and wetland breeding habitat at the southernmost end of the STS review area.

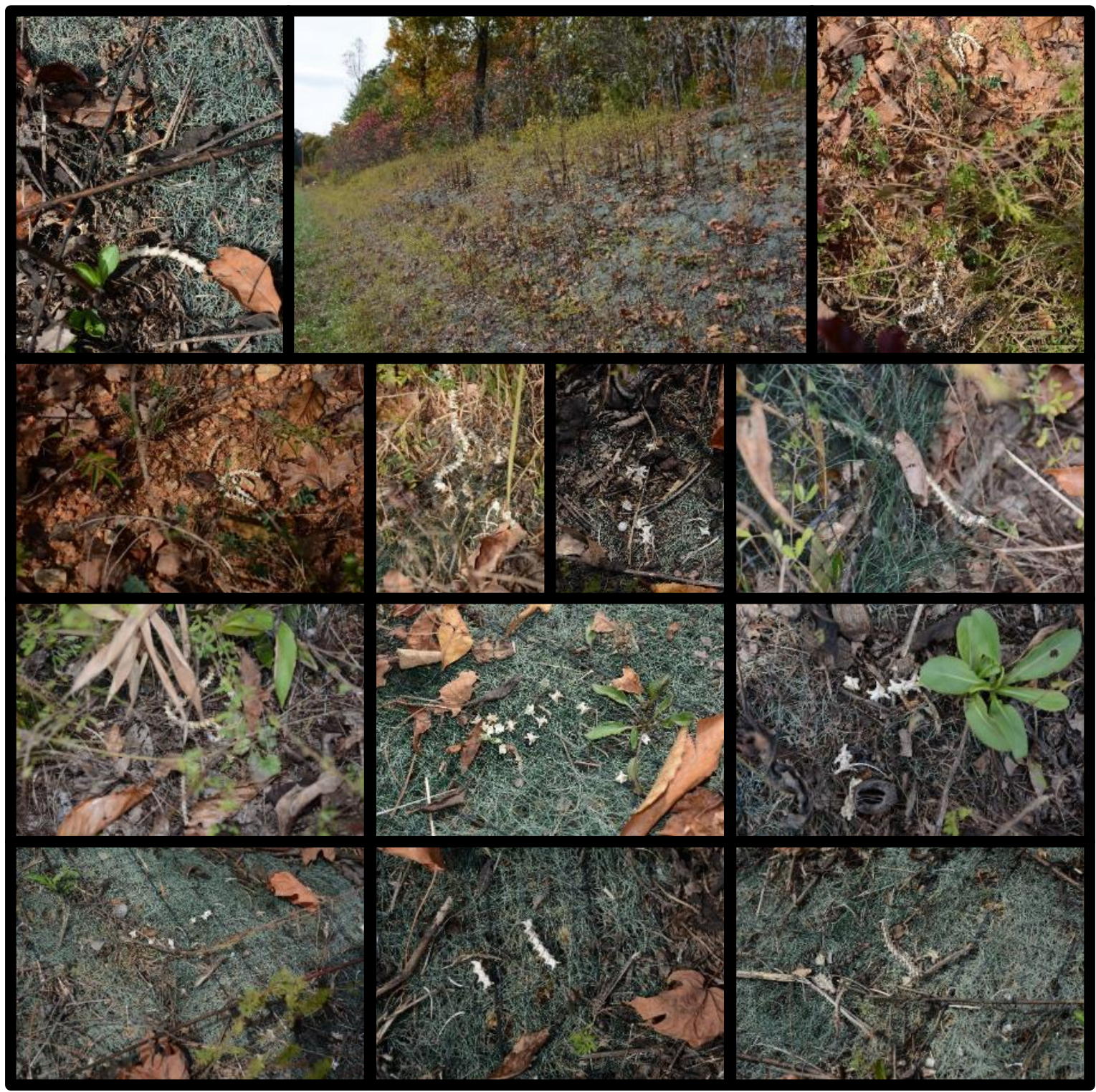

Figure 6. Representative images of reptile remains found in erosion netting during surveys along Perimeter Road in the northeastern portion of the survey area. 


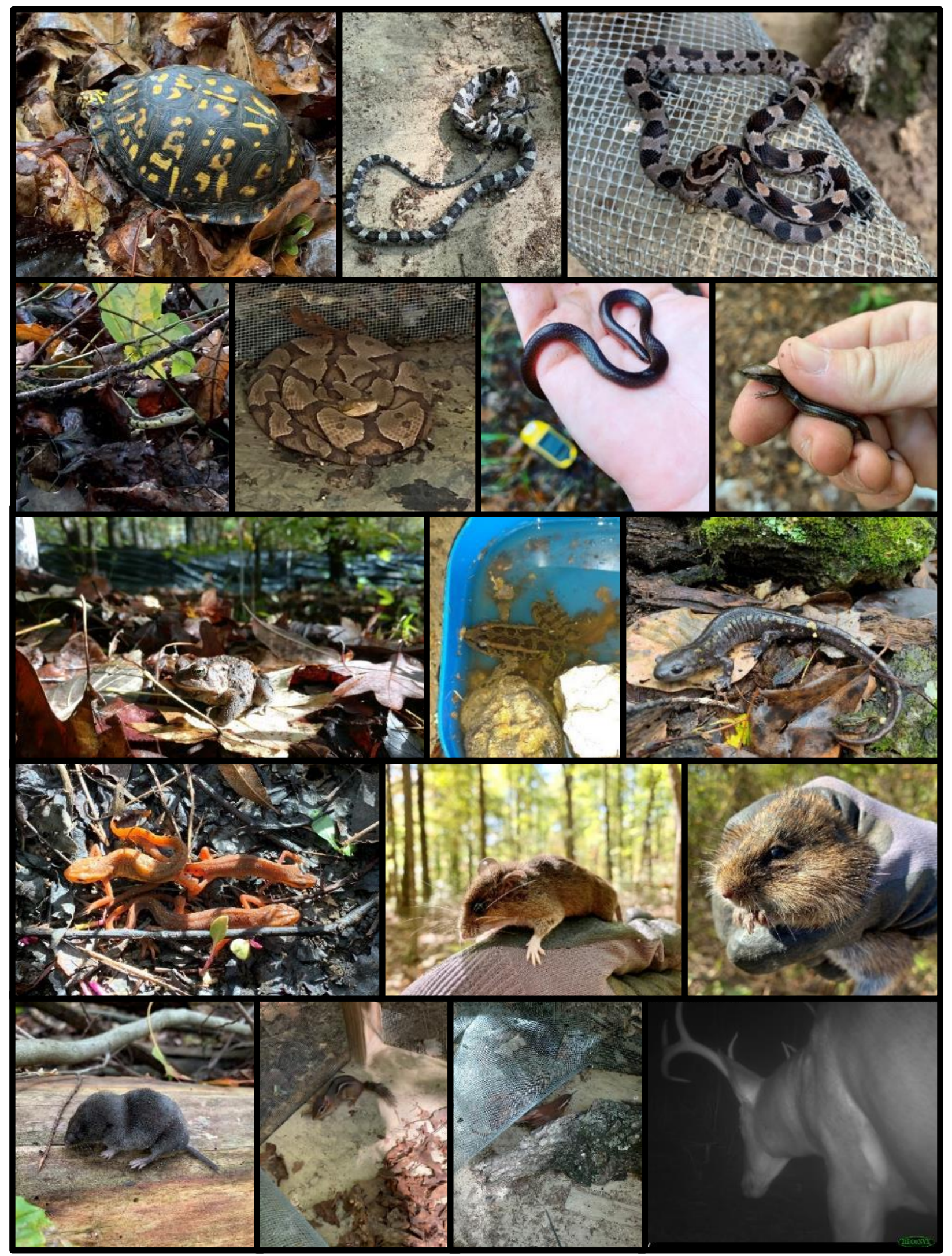

Figure 7. Examples of wildlife encountered during 2019 field surveys. 
Drift fence surveys (small vertebrates) (120 traps days and nights for a single 5-trap array)-50 species were captured in drift fence funnel arrays. This included 10 reptiles: copperhead (Agkistrodon contortrix), wormsnake (Carphophis amoenus), racer (Coluber constrictor), milksnake (Lampropeltis triangulum), cornsnake (Pantherophis guttatus), ratsnake (Pantherophis spiloides), five-lined skink (Plestiodon fasciatus), little brown skink (Scincella lateralis), box turtle (Terrapene carolina), and gartersnake (Thamnophis sirtalis); 10 amphibians: spotted salamander (Ambystoma maculatum), American toad (Anaxyrus americanus), narrow-mouthed toad (Gastrophryne carolinensis), American bullfrog (Lithobates catesbeianus), green frog (Lithobates clamitans), pickerel frog (Lithobates palustris), southern leopard frog (Lithobates sphenocephalus), eastern newt (Notphthalmus viridescens), slimy salamander (Plethodon glutinosus), and spring peeper (Pseudacris crucifer); 4 mammal species: Peromyscus spp., chipmunk (Tamias striatus), eastern mole (Scalopus aquaticus); and northern shottailed shrew (Blarina brevicauda); and 1 bird species: Carolina wren (Thryothorus ludovicianus). At least 35 invertebrate taxa were also identified as trap bycatch.

Compared to other sites on the ORR, the study area contained high richness and abundance of reptiles; average richness with high abundance of pond-breeding amphibians; and average richness and abundance of small mammals. No status species of amphibians or reptiles were documented during drift fence surveys. However, state-listed pine snakes (Pituophis melanoleucus) are expected, particularly within the dry, open forest in the northcentral portion of the survey area. Owing to their small population size and secretive nature, pine snakes are inherently difficult to detect, and species accumulation curves suggest that some rare species were not detected within the STS review area (Figure 8).

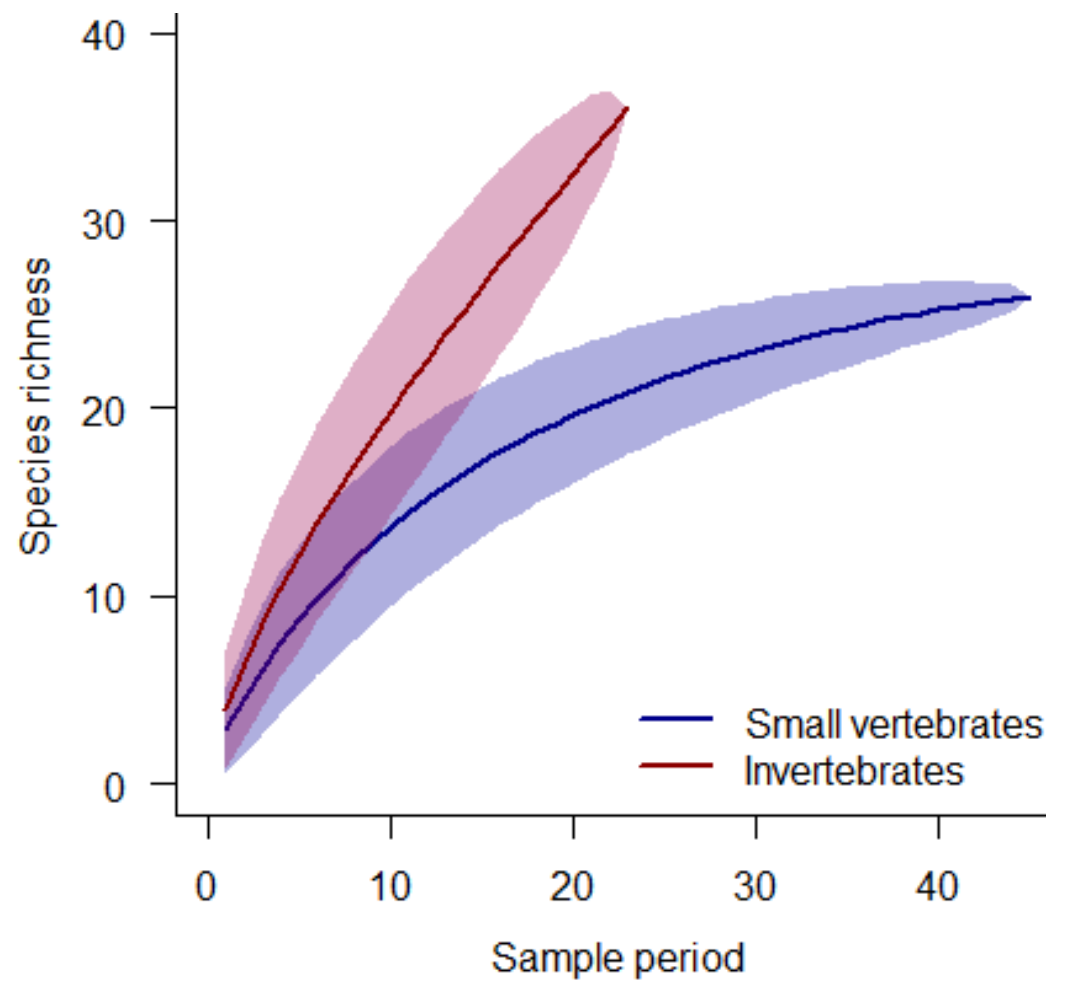

Figure 8. Species accumulation curves based on funnel trap captures of invertebrates (red) and small vertebrates (blue) from fall 2019 to summer 2020. Curves indicate the cumulative number of species captured through time and according to sample effort. Lines indicate observed cumulative richness, and shaded regions represent the interquartile range of simulated values. Lack of saturation in accumulation curves indicates likely incomplete sampling and failed detection of rare species for both invertebrates and small vertebrates (amphibians, reptiles, and small mammals). Lack of saturation was more extreme for invertebrate bycatch, as would be expected given the greater number of invertebrate species on the ORR. 


\subsubsection{Plant Surveys}

No new listed plant populations were found during 2019 to 2020 plant surveys, and no new significant disturbances of the vegetation were seen in the natural vegetation areas. The mature forest on the northwest side of the SNS appears unchanged. More than 100 whorled horsebalm (Collinsonia verticillata) plants and 5 sites for American ginseng (Panax quinquefolius) occur in this forest. A small population of pink lady-slipper (Cypripedium acaule) occurs in the southern portion of the survey area.

\subsubsection{Aquatic Resources}

The STS review area is primarily upland forest. However, it contains extensive wet weather conveyances, and portions of stream and wetland are intersected by the project area (Figure 9). If this project proceeds, permits and additional assessment will be required. Minimally, these would include wetland delineations (USACE 1987), stream evaluations (TDEC 2019), and hydrologic determinations of currently unclassified channels and wet weather conveyances (TDEC 2020). Owing to the presence of state-listed species, some sites might require additional assessment for the presence of Exceptional Tennessee Waters (TDEC 2015), but current wetland area of $<1$ acre suggests that avoidance of impacts to these areas is achievable with strategic site designs.

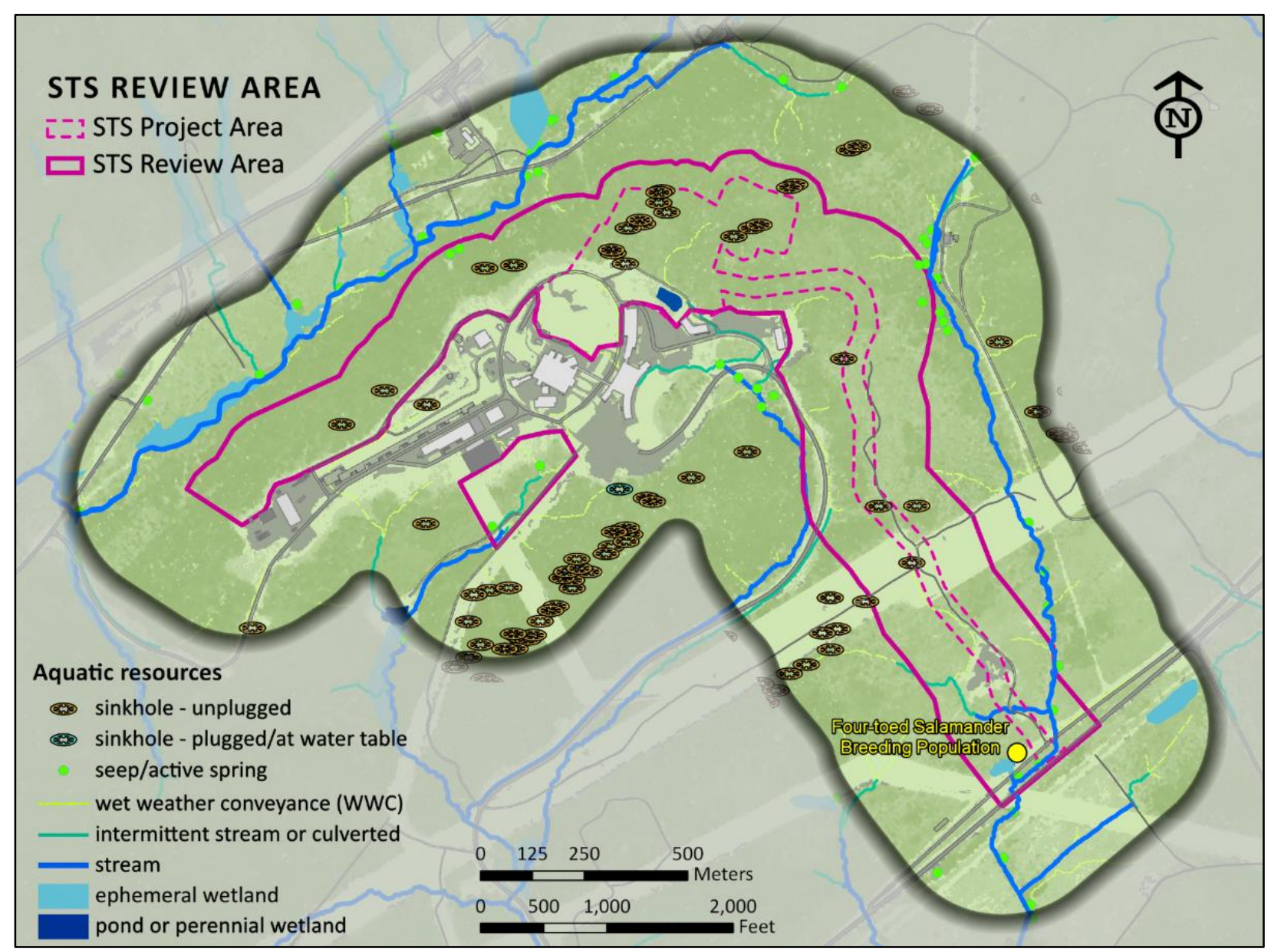

Figure 9. Aquatic resources within the STS review and project area (solid and dashed magenta line, respectively). Note the occurrence of streams and breeding population of the state-listed four-toed salamander (yellow circle) in the southeasternmost portion of the review area. 


\subsubsection{Additional Observations}

We compiled historical and incidental observations of sensitive resources for the SNS STS survey area from (1) prior observations made by ORNL NR or ESD staff during routine field surveys, (2) external researcher and contractor reports, and (3) TDEC's Natural Heritage Inventory Program, which contains various confirmed sources that date back as far as 1940 for much of the ORR. The STS survey area contained few historical plant and animal records. Among these were southern bog lemmings (Synaptomys cooperi), northern long-eared bats (Myotis septentrionalis), peregrine falcons (Falco peregrinus), slender glass lizards (Ophisaurus attenuatus), and American ginsengs (Panax quinquefolius).

All status species records, both contemporary and historical, for the STS project area are included in Figure 10 and Table 2 (see also Appendix III). Rare plants are excluded from maps and figures but are abundant in mature mesic forest within the survey area.

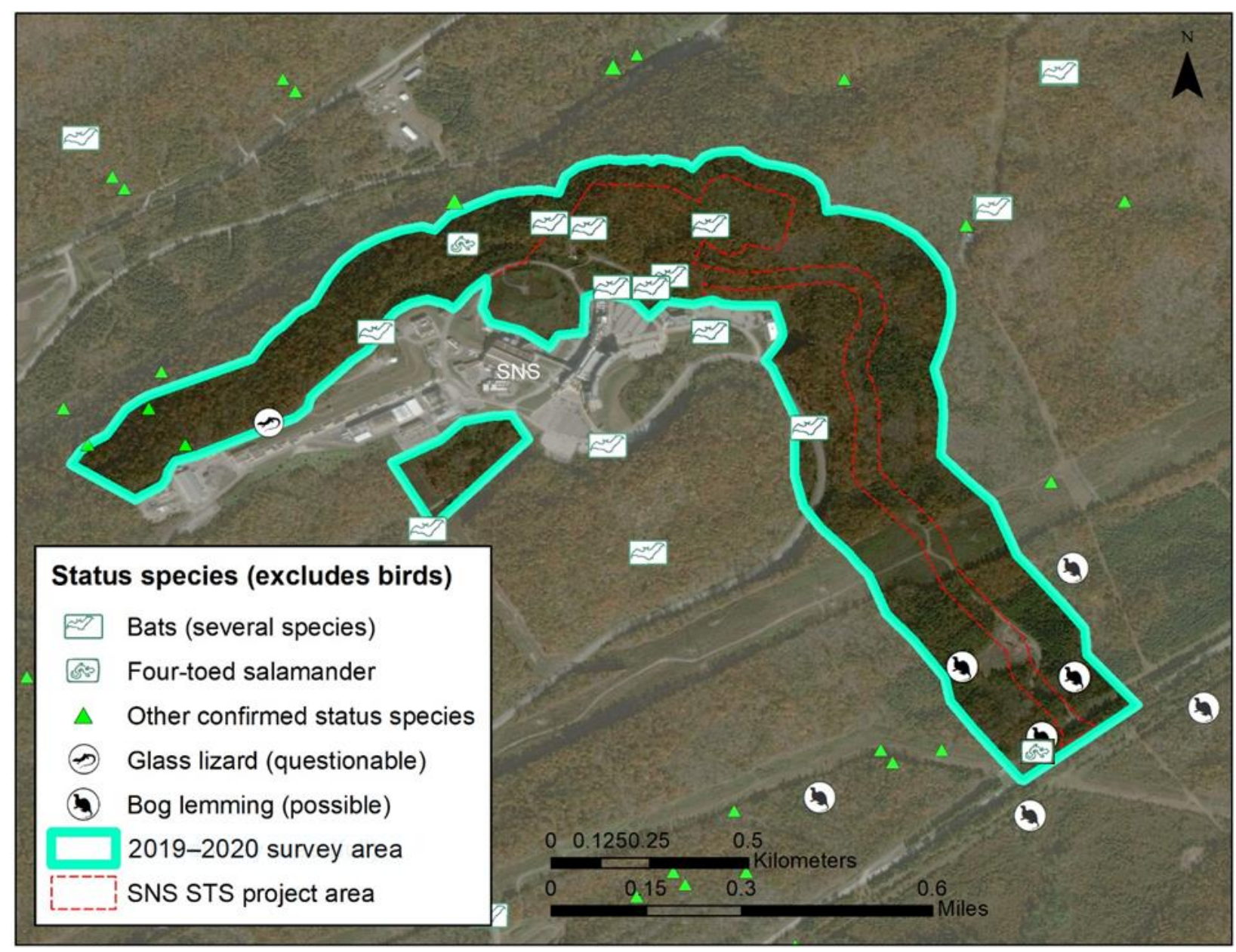

Figure 10. Status species locations, excluding birds. All bat points represent at least one federally listed species. The identities of some listed species were omitted (green triangles) because release of that information could compromise sensitive resources. 
Table 2. Status wildlife species present within the SNS STS project area based on historical (pre-1995) and contemporary observation (1995 to present). Status codes: SR: considered rare or regionally important by TDEC; SD: state deemed in need of management; ST: state threatened; SE: state endangered; FT: federally threatened;

FE: federally endangered; FP: federal listing petition currently under review; MBTA: protected under the MBTA; CBSD: PIF species designated as a common bird in steep decline. A complete list of species found in the STS project area can be found in Appendix III.

\begin{tabular}{|c|c|c|c|}
\hline Common name & Scientific name & Status & Notes \\
\hline \multicolumn{4}{|c|}{ Birds } \\
\hline Wood duck & Aix sponsa & MBTA + BMC & 2019-2020 \\
\hline Ruby-throated hummingbird & Archilochus colubris & MBTA & 2009 \\
\hline White-breasted nuthatch & Baeolophus bicolor & MBTA & 2009, 2019-2020 \\
\hline Red-shouldered hawk & Buteo lineatus & MBTA & 2009 \\
\hline Red-tailed hawk & Buteo jamaicensus & MBTA & 2019-2020 \\
\hline Broad-winged hawk & Buteo platypterus & MBTA & $2009,2019-2020$ \\
\hline Blue-gray gnatcatcher & Polioptila caerulea & MBTA & 2019-2020 \\
\hline American crow & Corvus brachyrhynchos & MBTA & 2019-2020 \\
\hline American robin & Turdus migratorius & MBTA & $\begin{array}{c}\text { 2019-2020 } \\
\text { Barn swallow }\end{array}$ \\
\hline Brown-headed cowbird & Mylothrus ater & MBTA & 2019-2020 \\
\hline Common grackle & Quiscalus quiscula & $\mathrm{MBTA}+\mathrm{CBSD}$ & 2019-2020 \\
\hline Chipping sparrow & Spizella passerina & MBTA & 2019-2020 \\
\hline Common yellowthroat & Geothylpis trichas & MBTA & 2019-2020 \\
\hline Northern cardinal & Cardinalis cardinalis & MBTA & $2009,2019-2020$ \\
\hline Yellow-billed cuckoo & Coccyzus americanus & $\mathrm{MBTA}+\mathrm{CBSD}$ & 2009 \\
\hline Red-winged blackbird & Agelaius phoeniceus & MBTA & 2019-2020 \\
\hline Northern flicker & Colaptes auratus & MBTA & \\
\hline Eastern wood-pewee & Contopus virens & MBTA & 2009 \\
\hline American crow & Corvus brachyrhynchos & MBTA & 2009, 2019-2020 \\
\hline Blue jay & Cyanocitta cristata & MBTA & $2009,2019-2020$ \\
\hline Pileated woodpecker & Dryocopus pileatus & MBTA & 2009, 2019-2020 \\
\hline Acadian flycatcher & Empidonax virescens & MBTA & 2009 \\
\hline Peregrine falcon & Falco peregrinus & $\begin{array}{c}\mathrm{MBTA}+\mathrm{BMC} \\
\mathrm{BCC}\end{array}$ & Historical, likely transient \\
\hline Barn swallow & Hirundo rustica & MBTA & 2009 \\
\hline Tree swallow & Tachycineta bicolor & MBTA & 2019-2020 \\
\hline Red-bellied woodpecker & Melanerpes carolinus & MBTA & $2009,2019-2020$ \\
\hline Song sparrow & Melospiza melodia & MBTA & $2009,2019-2020$ \\
\hline Northern mockingbird & Mimus polyglottos & MBTA & 2019-2020 \\
\hline Blue grosbeak & Passerina caerulea & MBTA & 2009 \\
\hline Northern parula & Setophaga americana & MBTA & 2019-2020 \\
\hline Prairie warbler & Setophaga discolor & MBTA & 2019-2020 \\
\hline Indigo bunting & Passerina cyanea & MBTA & 2009 \\
\hline Savannah sparrow & Passerculus sandwichensis & $\mathrm{MBTA}+\mathrm{SR}$ & 2019-2020 \\
\hline Downy woodpecker & Picoides pubescens & MBTA & 2009, 2019-2020 \\
\hline Eastern towhee & Pipilo erythrophthalmus & MBTA & $2009,2019-2020$ \\
\hline Scarlet tanager & Piranga olivacea & MBTA & $2009,2019-2020$ \\
\hline Summer tanager & Piranga rubra & MBTA & 2009, 2019-2020 \\
\hline
\end{tabular}


Table 2. Status wildlife species present within the SNS STS project area based on historical (pre-1995) and contemporary observation (1995-present).

\begin{tabular}{|c|c|c|c|}
\hline Common name & Scientific name & Status & Notes \\
\hline \multicolumn{4}{|c|}{ Birds (continued) } \\
\hline Scarlet Tanager & Catharus ustslatus & MBTA & 2019-2020 \\
\hline Carolina Chickadee & Poecile carolinensis & MBTA & $2009,2019-2020$ \\
\hline Eastern Phoebe & Sayornis phoebe & MBTA & 2009, 2019-2020 \\
\hline Hooded Warbler & Setophaga citrina & MBTA & 2019-2020 \\
\hline Yellow Warbler & Setophaga petechia & MBTA & 2019-2020 \\
\hline Chestnut-Sided Warbler & Setophaga pensylvanica & MBTA & 2019-2020 \\
\hline Pine Warbler & Setophaga pinus & MBTA & 2009-2020 \\
\hline Yellow-breasted Chat & Icteria virens & MBTA & 2019-2020 \\
\hline Eastern Bluebird & Sialia sialis & MBTA & 2009, 2019-2020 \\
\hline Yellow-Bellied Sapsucker & Sphyrapicus varius & $\begin{array}{c}\text { MBTA + BMC, } \\
\text { BCC }\end{array}$ & 2009 \\
\hline American Goldfinch & Spinus tristis & MBTA & 2009, 2019-2020 \\
\hline White-Breasted Nuthatch & Sitta carolinensis & MBTA & 2009, 2019-2020 \\
\hline Field Sparrow & Spizella pusilla & $\mathrm{MBTA}+\mathrm{CBSD}$ & 2009, 2019-2020 \\
\hline Eastern Meadowlark & Sturnella magna & MBTA + CBSD & 2019-2020 \\
\hline Carolina Wren & Thryothorus ludovicianus & MBTA & 2009, 2019-2020 \\
\hline Red-Eyed Vireo & Vireo olivaceus & MBTA & 2009, 2019-2020 \\
\hline White-eyed Vireo & Vireo griseus & MBTA & 2019-2020 \\
\hline Yellow-Throated Vireo & Vireo flavifrons & MBTA & 2009 \\
\hline White-throated sparrow & Zonotrichia albicollis & MBTA & 2019-2020 \\
\hline House Finch & Haemorhous mexicanus & MBTA & 2019-2020 \\
\hline European Starling & Sturnus vulgaris & & 2019-2020 \\
\hline Mourning Dove & Zenaida macroura & MBTA + BMC & 2009, 2019-2020 \\
\hline Wild Turkey & $\begin{array}{l}\text { Meteagris gallopava } \\
\text { silvestris }\end{array}$ & MBTA & 2019-2020 \\
\hline \multicolumn{4}{|c|}{ Mammals } \\
\hline Rafinesque's big-eared bat & Corynorhinus rafinesquii & SD & 2019, probable $^{\dagger}$ \\
\hline Southeastern myotis & Myotis austroriparius & SR & 2019, unlikely \\
\hline Grey bat & Myotis grisescens & $\mathrm{SE}+\mathrm{FE}$ & 2019-2020 \\
\hline Eastern small-footed bat & Myotis leibii & SD & 2019-2020 \\
\hline Little brown bat & Myotis lucifugus & ST & 2019 \\
\hline Northern long-eared bat & Myotis septentrionalis & $\mathrm{ST}+\mathrm{FT}$ & Historical, probable ${ }^{\dagger}$ \\
\hline Indiana bat & Myotis sodalis & $\mathrm{SE}+\mathrm{FE}$ & 2019-2020, probable ${ }^{\dagger}$ \\
\hline Tricolored bat & Perimyotis subflavus & $\mathrm{FP}+\mathrm{ST}$ & 2019-2020 \\
\hline Southern bog lemming & Synaptomys cooperi & SD & Historical $^{\S}$ \\
\hline \multicolumn{4}{|c|}{ Amphibians } \\
\hline Four-toed salamander & $\begin{array}{l}\text { Hemidactylium scutatum } \\
\text { Reptiles }\end{array}$ & SD, ORNL FP & 2009-2020 \\
\hline Eastern slender glass lizard & Ophisaurus attenuatus & SD & Historical, questionable \\
\hline
\end{tabular}

${ }^{*}$ Record is historical and confirmed, but nesting habitat is not apparent within site.

$\dagger$ Record based on few acoustic monitor detections, but presence is assumed given habitat and nearby records.

$\$$ Record based on only one or two acoustic monitor detections; presence is unlikely.

$\S$ Records predate ORNL Natural Resources Program. Targeted surveys in 2020 failed to detect this species.

I Questionable contemporary (2019) record based on skeletal remains of recently deceased individual. 


\subsection{FOREST INVENTORY}

Forest cover and land use - Land use categories in the STS survey area include forest, rights-of-way, developed areas, and edge. Forest comprises approximately $75.6 \%$ (169.40 acres) of the area, followed by developed areas $(12.3 \%, 27.39$ acres) and rights-of-way $(11.1 \%, 24.75$ acres) (Figure 11). Less than 1\% (1.44 acres, located between Bethel Valley and Old Bethel Valley Roads) would be considered edge (Figure 11). Thirty-six tree species from 23 genera were documented within the STS survey area (Table 3). Spatial distributions of selected dominant species (>20\% basal area at sample points) and additional details regarding forest conditions can be found in Appendix II.

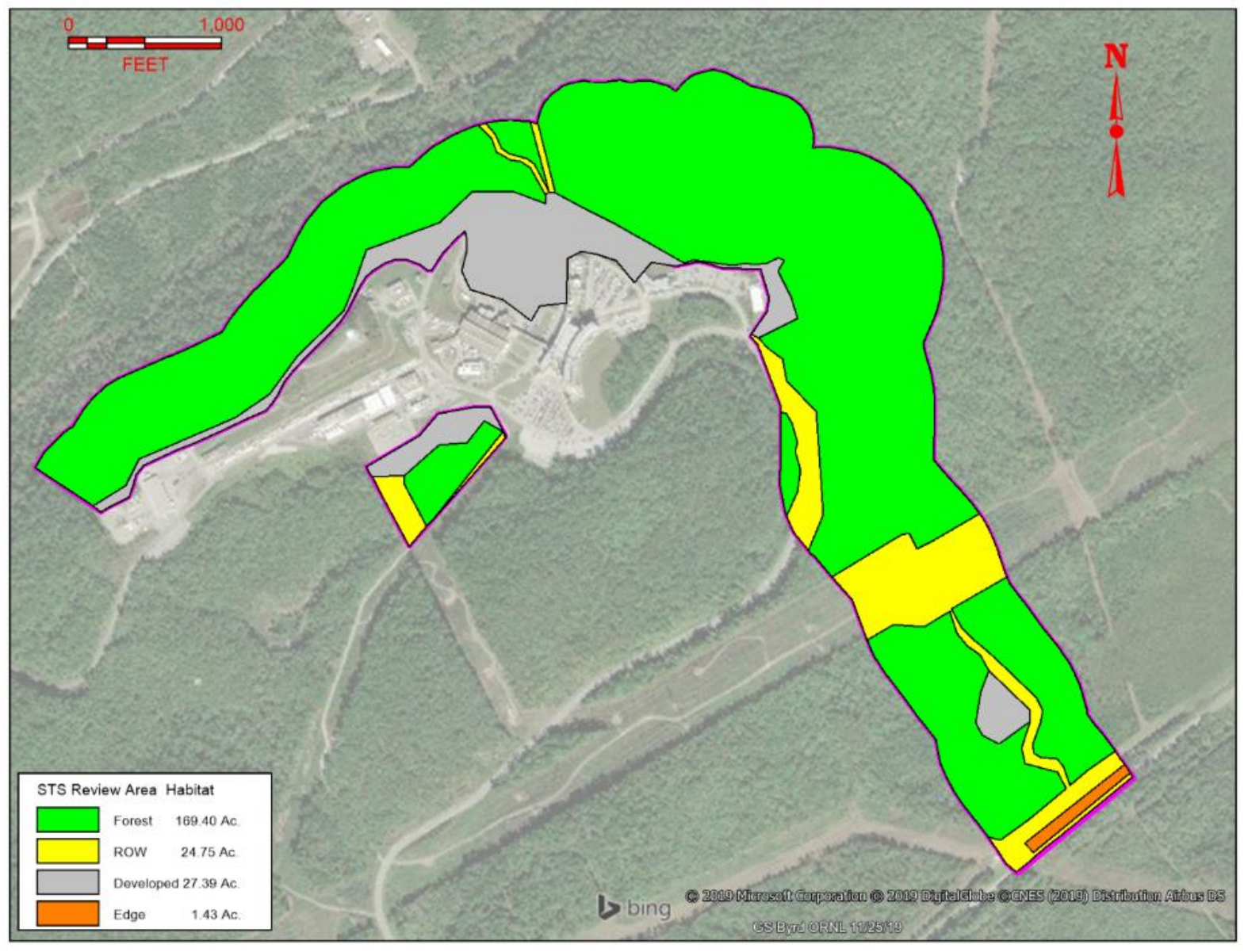

Figure 11. Forest cover and land use within the STS project area based on 2013 forest inventory data. 
Table 3. List of 36 tree species inventoried within the STS survey area.

\begin{tabular}{|c|c|c|}
\hline Species & Common name & Status \\
\hline Acer rubrum & Red maple & Native \\
\hline Acer saccharum & Sugar maple & Native \\
\hline Aralia spinosa & Devil's walking stick & Native \\
\hline Carya cordiformis & Bitternut hickory & Native \\
\hline Carya glabra & Pignut hickory & Native \\
\hline Carya tomentosa & Mockernut hickory & Native \\
\hline Celtis occidentalis & Hackberry & Native \\
\hline Cercis canadensis & Eastern redbud & Native \\
\hline Cornus florida & Flowering dogwood & Native \\
\hline Fagus grandifolia & American beech & Native \\
\hline Fraxinus americana & White ash & Native \\
\hline Juglans nigra & Black walnut & Native \\
\hline Juniperus virginiana & Eastern redcedar & Native \\
\hline Liquidambar styraciflua & Sweetgum & Native \\
\hline Liriodendron tulipifera & Tulip poplar & Native \\
\hline Morus rubra & Red mulberry & Native \\
\hline Nyssa sylvatica & Black gum & Native \\
\hline Oxydendron arboreum & Sourwood & Native \\
\hline Paulownia tomentosa & Princess tree & Non-native, invasive \\
\hline Pinus echinata & Shortleaf pine & Native \\
\hline Pinus strobus & White pine & Native \\
\hline Pinus taeda & Loblolly pine & Native \\
\hline Pinus virginiana & Virginia pine & Native \\
\hline Plantanus occidentalis & American sycamore & Native \\
\hline Prunus serotina & Black cherry & Native \\
\hline Pyrus calleryana & Callery pear & Non-native, invasive \\
\hline Quercus alba & White oak & Native \\
\hline Quercus coccinea & Scarlet oak & Native \\
\hline Quercus falcata & Southern red oak & Native \\
\hline Quercus montana & Chestnut oak & Native \\
\hline Quercus rubra & Northern red oak & Native \\
\hline Quercus stellata & Post oak & Native \\
\hline Quercus velutina & Black oak & Native \\
\hline Sassafras albidum & Sassafras & Native \\
\hline Ulmus alata & Winged elm & Native \\
\hline Ulmus rubra & Slippery elm & Native \\
\hline
\end{tabular}

Land use history and cultural resources-Figure 12 depicts a topographic map of the STS survey area as it appeared in 1941, immediately prior to acquisition by the federal government during the Manhattan Project. Forested areas at that time are highlighted and occupied $48.3 \%$ of the site (107.8 acres), and the balance $(41.7 \%, 115.2$ acres) was open fields. 


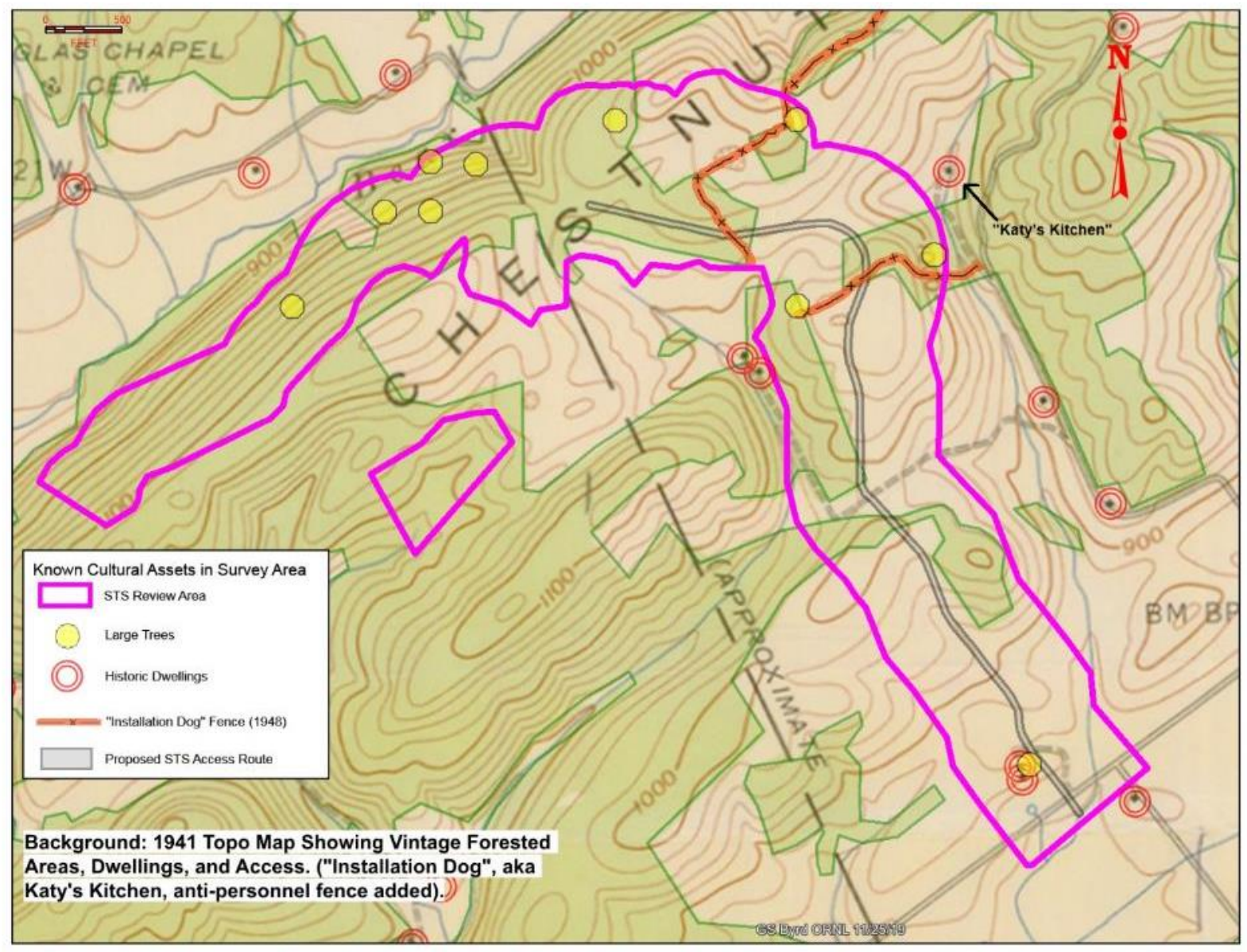

Figure 12. Historic and cultural resources within the survey area.

The STS survey area comprises lands from 12 acquisition parcels but contains the remnants of dwellings of only 1 of these parcels (Tract G-601, from "Hiram P. Carter and wife"). The survey area also contains a segment of a driveway connecting a nearby homeplace (Tract B143, Charles E. Brennan) to what is now known as 0907 Access Road. No other preconstruction era features appear within the survey area.

The review era contains a significant portion of an artifact of the cold war era, namely the remains of a double apron anti-personnel fence, surrounding Building 0907 (Katy's Kitchen). Originally referred to as "Installation Dog" in 1948, the 0907 site was a discrete repository for plutonium and the area surrounding it protected by a "GI combat-type barbed wire fence, and rigged with a very elaborate alarm system" (Ruby A. Miller, Union Carbide Nuclear Division News, 1973, as reprinted in ORNL Publication ORNL/M-2732, 2008). An example of this type of obstacle is represented in Figure 13. Remains of the fence include its iron pickets ( 4 in. posts and shorter stakes, barbed wire [on ground and embedded in trees], and metal warning postings [no longer legible]). Whatever the historical significance of the fence may be, the barbed wire and several dozens of rebar posts and stakes, some difficult to discern among the deep leaf litter, may present hazards to STS construction personnel and equipment during site development. 


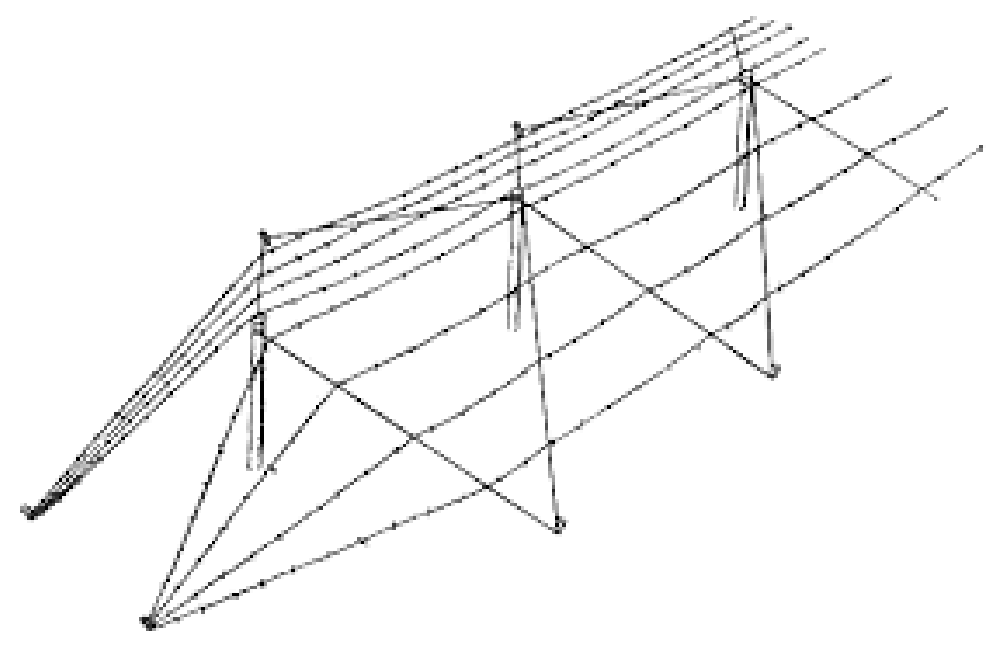

Figure 13. Example of the type of double apron obstacle found within the survey area near Building 0907 (Katy's Kitchen).

A review of ORNL Forest Management records indicates that open areas outside the Installation Dog fence were planted with loblolly pine in 1955. The pine was thinned in 1970, 1971, and 1985, and finally harvested in 2000 during the most recent southern pine beetle epidemic and land clearing for the SNS project.

Selective harvesting of most of the survey area's hardwood timber took place in 1972 in the areas east of Chestnut Ridge Drive and in 1977 for the areas to the west. Additionally, clear-cutting occurred among these hardwoods in 1999 and 2000 ahead of SNS site development.

\section{CONCLUSIONS}

This report includes a compilation of new and existing data regarding sensitive flora and fauna, forest condition, and cultural and historical resources that might be impacted by the proposed STS project. In total, 111 species of wildlife were documented within the survey area (Appendix III). Of these, at least 10 species are afforded special legal protection under state or federal law (USFWS), in addition to 59 bird species that are afforded protection under the MBTA (16 U.S.C. §\$703-711). Few special status plant species occur within the STS project area.

The highest richness and diversity of sensitive resources in the STS survey area appears to occur where the primary development of the STS facilities is proposed (in the northeastern to central portion of the survey area). This area contains a large number of sinks and macropores that provide a high degree of heterogeneity at the landscape and microhabitat levels. Such heterogeneity is simultaneously expected to support a greater number of rare species while reducing detectability (greater niche space while reducing the efficacy of generalized survey methods). The holding pond along the perimeter road also adds considerable value in an otherwise well-drained landscape, as evidenced by the presence of several pondbreeding amphibians. A borderline ephemeral wetland also exists nearby in what appears to be suitable habitat for state-listed four-toed salamanders.

The northeastern to central portions of the survey area also produced the greatest number of reptiles during VESs. These areas contain some of the most suitable habitat for pine snakes on the ORR. Although not detected during surveys, pine snakes might occur given historical records in nearby areas and the suitably dry forest and infertile soils that characterize the area. Eastern slender glass lizards 
should not be considered present until additional specimens are discovered. However, likely habitat exists along edges and open canopy habitats with infertile soils surrounding SNS.

The only federally listed species within the STS project area are bats. At least three status bat species were considered present, with four additional status species expected with very high confidence (Tables 1a and $1 \mathrm{~b}$ ). The northeastern to central portion of the study area is likewise expected to harbor unusually high bat richness and abundance owing to a high density of potential roost trees. Acoustic monitors also detected a high number of calls within this area later than what existing guidance suggests for reliable detection (USFWS 2017).

The southern portion of the STS project area, from Bethel Valley Road to the primary facility expansion area, contains the widest range of habitat types. However, the thick understory (within forest and rightsof-way) deemed much of this area difficult to survey. State-listed southern bog lemmings were once abundant within the lower, moist habitats nearest Bethel Valley Road. This species represents another questionable occurrence within the STS project area. Suitable habitat was largely eliminated during construction of much of the ORNL campus, and targeted surveys during summer 2020 failed to detect this species.

\subsection{MITIGATION}

TDEC and TWRA must be notified immediately concerning known impacts to state-listed fauna if the STS project proceeds. Moreover, acceptable mitigation measures for many species, notably bats, depend on the type of habitat (e.g., foraging, roosting, hibernacula). Given that the primary planned construction area of the STS site contains extensive roost habitat for federally listed bats, and federally listed bats were detected via acoustic survey, at least informal consultation with USFWS should be initiated immediately (USFWS 2017). Minimally, informal consultation between DOE and USFWS will also be required for migratory birds under existing agreements between USFWS and DOE (66 FR 3853; for additional details of the responsibilities of DOE under the MBTA, see Carter et al. 2020).

Avoidance of sensitive resources is the preferred first approach. Consultation between USFWS and DOE will determine avoidance and mitigation measures for bats and migratory birds. At the state level, the wetland and small number of streams might be avoided via minimal changes to site design. This would reduce or eliminate necessary permitting and potential mitigation of aquatic resources, as required at the state and federal levels (TDEC 2015, 2019, 2020). Furthermore, two major mitigation strategies might be proposed to offset impacts of STS construction and operation at the state (but not federal) level. These include (1) removal of the synthetic erosion netting that surrounds the SNS facility and SNS Access Road and (2) invasive plant control and restoration of the wetland and moist forest at the southern end of the project area. 


\section{REFERENCES}

Carter, E. T., N. R. Giffen, K. McCracken, S. E. Darling, A. Deck, and G. Byrd. 2020. Wildlife Management Plan for the Oak Ridge Reservation. ORNL/TM-2012/387/R1. Oak Ridge National Laboratory, Oak Ridge, Tennessee.

Giffen, N., S. Reasor, G. Byrd, L. Pounds, C. Waggoner, and C. Campbell. 2009. Environmental Survey Report for SNS: Target Building \#2. Unpublished technical report. Oak Ridge National Laboratory, Oak Ridge, Tennessee.

Nicholson, C. P. 1997. Atlas of Breeding Birds of Tennessee. University of Tennessee Press, Knoxville, Tennessee, U.S.A.

TDEC (Tennessee Department of Environment and Conservation). 2015. Tennessee Rapid Assessment Method (TRAM). Division of Water Resources Natural Resources Unit, Nashville, Tennessee.

TDEC (Tennessee Department of Environment and Conservation). 2019. Stream Mitigation Guidelines. https://www.tn.gov/content/dam/tn/environment/water/policy-and-guidance/dwr-nr-g-01-streammitigation-guidelines-052019.pdf.

TDEC (Tennessee Department of Environment and Conservation). 2020. Guidance for Making Hydrologic Determinations Version 1.5. Division of Water Pollution Control, Nashville, Tennessee. https://www.tn.gov/content/dam/tn/environment/water/policy-and-guidance/dwr-nr-g-03-hydrologicdeterminations\%E2\%80\%9304012020.pdf.

TWRA (Tennessee Wildlife Resources Agency). 2016. Threatened and Endangered Species List Rules. Available at https://www.tn.gov/content/tn/twra/wildlife.html\#endangered. Accessed on November 10, 2019.

USFWS (US Fish and Wildlife Service). 2011. "Birds of Management Concern and Focal Species." Available at https://www.fws.gov/migratorybirds/pdf/management/BMCFocalSpecies.pdf. Accessed on November 10, 2019.

USFWS (US Fish and Wildlife Service). 2017. Conservation Strategy for Forest-dwelling Bats in Tennessee. Available at https://www.fws.gov/cookeville/pdfs/TN_Conserv_Strat_forest_dwelling_bats_171005.pdf. Accessed on November 10, 2019.

USFWS (US Fish and Wildlife Service). 2019. ECOS Environmental Conservation Online System. Retrieved from https://ecos.fws.gov/ecp0/reports/ad-hoc-species-report-input. Accessed on November $10,2019$.

USFWS (US Fish and Wildlife Service). 2019. Endangered Species. Retrieved from https://www.fws.gov/endangered/index.html. Accessed on November 10, 2019.

Wade, B. and E. T. Carter. 2020. Modelling barriers to aquatic-terrestrial wildlife movement on the Oak Ridge Reservation. Oak Ridge National Laboratory, Oak Ridge, Tennessee.

Wade, B., C. R. DeRolph, and E. T. Carter. In preparation. Optimizing connectivity of imperiled fourtoed salamanders (Hemidactylium scutatum) on the Oak Ridge Reservation, Tennessee, USA. Oak Ridge National Laboratory, Oak Ridge, Tennessee. 


\section{APPENDIX I. METHODS AND RESULTS FOR 2009 SURVEYS}

Giffen, N., S. Reasor, G. Byrd, L. Pounds, C. Waggoner, and C. Campbell. 2009. Environmental Survey Report for SNS: Target Building \#2. Unpublished technical report. Oak Ridge National Laboratory, Oak Ridge, Tennessee.

\section{I.1 METHODS}

Figure I.1 depicts the surveys conducted on the SNS site for the evaluation of alternatives. The following is a brief description of the methods used during the study.

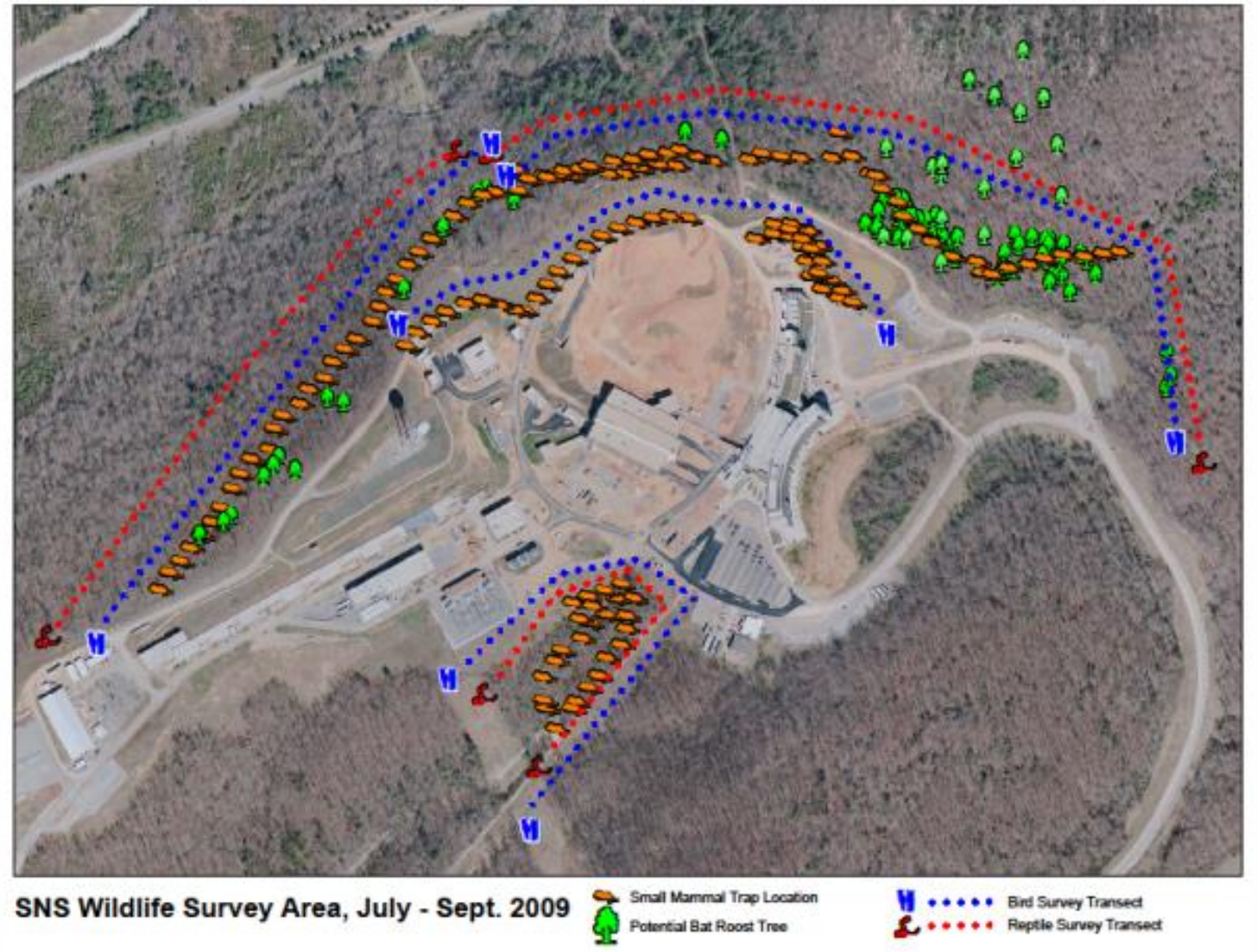

Figure I.1. Natural resources survey map.

Bird survey - A series of transect surveys of site habitats were conducted during the morning hours. During that time, all birds either heard or seen were recorded. Incidental encounters with birds were also recorded during surveys of other natural resources. Additionally, any sign (e.g., woodpecker drillings) was noted where it could be identified to the species.

Small mammal survey - Small mammal surveys were conducted at the site using Sherman live traps. A total of 145 traps were set out on the site covering all habitats. Small mammals were trapped for 7 nights during a 2-week period for a total of 1,015 trap nights ( 7 nights $\times 145$ traps). All captured small mammals were identified and released at the location of capture. Incidental encounters with mammals were also recorded during surveys of other natural resources. 
Reptile and amphibian survey - One-day VESs were conducted in all site habitats. This involved searching under logs, rocks, bark, leaf litter, and other debris. All reptiles and amphibians encountered were identified and recorded. Incidental encounters with reptiles and amphibians were also recorded during surveys of other natural resources.

Vegetation survey - Walk-through surveys of each habitat were conducted at which time all vascular plant species that could be identified were recorded. Additional surveys were conducted with a professional plant ecologist to specifically identify rare plants. The ORNL forester also surveyed the site to evaluate trees for potential significance and marketability.

Survey of potential bat roosting habitat - A visual survey of trees was conducted on the site to determine the presence of potential bat roosting habitat. All trees containing potential bat habitat were flagged for mapping at a later date.

Global positioning system (GPS) survey point locations - GPS locations were recorded for all natural resource survey transects and points. GPS locations for potential bat roosting trees at the site were also recorded. A Trimble unit was used to record all locations.

\section{I.2 RESULTS}

The results of the natural resources surveys are presented by habitat type and associated with each alternative as appropriate because each alternative spans more than one habitat type. Alternatives \#1 and \#3, in particular, are associated with the same habitat types on the north side of the facility. Alternative \#2 is associated with a separate area on the west side of the facility.

\section{I.2.1 Habitats in the Area of Alternatives \#1 and \#3}

\section{I.2.1.1 Dry Upland Forest}

This dry upland forest is characterized by rolling hills, swales, and moderate slopes. The area slopes upward and eastward on the site from the moister, more steeply sloping forested area to the west. Chestnut Ridge Road is a defining boundary between the drier and moister forested areas at the site. This forest is bordered on the south by a relatively sharp edge in most locations that is characterized by grassy fields, scattered shrubs, and disturbed areas.

Bird survey results - A total of 15 bird species were identified in this habitat by either sight or song. Sign was noted for two additional species.

There was sign (tree drillings) noted for one species, the yellow-bellied sapsucker (Sphyrapicus varius), which is on the federal "species of management concern" and state "in need of management" list. This species is a fairly common winter visitor on the ORR but is not present during the breeding season. Wild turkey (Meleagris gallopavo) scrapes were also noted in the leaf litter on the site.

Five species were recorded at the site that are on the PIF list as being of regional importance in the ridge and valley. PIF monitors population trends based on data gathered throughout the region and lists species that are in apparent decline. Of greatest concern are species that are considered to be impacted by forest fragmentation (i.e., interior forest species). Species in this category that were noted in this habitat on and adjacent to the project site are broad-winged hawk (Buteo platypterus), downy woodpecker (Picoides pubescens), eastern-wood pewee (Contopus virens), scarlet tanager (Piranga olivacea) and summer tanager (Piranga rubra). Two other notable forest birds recorded on the site are the red-shouldered hawk (Buteo lineatus) and pileated woodpecker (Dryocopus pileatus). The two hawk species (broad-winged 
and red-shouldered) were flyovers. (Ovenbird [Seiurus aurocapillus] has been recorded in this area during previous surveys. The ovenbird is an interior forest bird.) A complete bird list for the dry forest is provided in Table I.1.

Table I.1. Bird species list for the dry forest.

\begin{tabular}{|c|c|c|c|c|}
\hline \multirow[b]{2}{*}{ Scientific name } & \multirow[b]{2}{*}{ Common name } & \multicolumn{3}{|c|}{ Status } \\
\hline & & Federal & State & PIF \\
\hline \multicolumn{5}{|c|}{ Kites, hawks, eagles, and allies } \\
\hline Buteo lineatus & Red-shouldered hawk & & & \\
\hline Buteo platypterus & Broad-winged hawk & & & RI \\
\hline \multicolumn{5}{|l|}{ Pheasants and turkeys } \\
\hline Meleagris gallopavo & Wild turkey & & & \\
\hline \multicolumn{5}{|c|}{ Cuckoos, roadrunners, and anis } \\
\hline Coccyzus americanus & Yellow-billed cuckoo & & & \\
\hline \multicolumn{5}{|l|}{ Woodpeckers } \\
\hline Sphyrapicus varius & Yellow-bellied sapsucker & $\mathrm{MC}$ & NM & \\
\hline Melanerpes carolinus & Red-bellied woodpecker & & & \\
\hline Picoides pubescens & Downy woodpecker & & & RI \\
\hline Dryocopus pileatus & Pileated woodpecker & & & \\
\hline \multicolumn{5}{|l|}{ Tyrant flycatchers } \\
\hline Sayornis phoebe & Eastern phoebe & & & \\
\hline Contopus virens & Eastern wood-pewee & & & RI \\
\hline \multicolumn{5}{|l|}{ Nuthatches } \\
\hline Sitta carolinensis & White-breasted nuthatch & & & \\
\hline \multicolumn{5}{|l|}{ Wrens } \\
\hline Thryothorus ludovicianus & Carolina wren & & & \\
\hline \multicolumn{5}{|l|}{ Vireos } \\
\hline Vireo olivaceus & Red-eyed vireo & & & \\
\hline \multicolumn{5}{|l|}{ Crows and jays } \\
\hline Cyanocitta cristata & Blue jay & & & \\
\hline Corvus brachyrhynchos & American crow & & & \\
\hline \multicolumn{5}{|l|}{ Tanagers } \\
\hline Piranga olivacea & Scarlet tanager & & & RI \\
\hline Piranga rubra & Summer tanager & & & RI \\
\hline
\end{tabular}

$\mathrm{MC}=$ species of management concern, $\mathrm{NM}=$ in need of management, $\mathrm{RI}=$ regional importance

Small mammal survey results-A total of 25 Sherman live traps were set out in the dry upland forest habitat. Small mammals were trapped for 7 nights during a 2-week period for a total of 175 trap nights (7 nights $\times 25$ traps).

The white-footed mouse (Peromyscus leucopus) was the only species of small mammal captured in traps in this habitat. Eastern chipmunks (Tamias striatus) and gray squirrels (Sciurus carolinensis) were also recorded incidentally while conducting other surveys. Sign of coyote (Canis latrans) (scat) and whitetailed deer (Odocoileus virginianus) (scat and tracks) were also noted. 
Reptile and amphibian survey-A one-day VES was conducted in the dry upland forest habitat. This involved searching under logs, rocks, bark, leaf litter, and other debris. All reptiles and amphibians found were recorded. Incidental encounters with reptiles and amphibians were also recorded during surveys of other natural resources.

All reptiles and amphibians recorded for this habitat are considered to be common on the ORR. Species recorded included the eastern box turtle (Terrapene carolina carolina), gray treefrog (Hyla versicolor), Cope's gray treefrog (Hyla chrysoscelis), five-lined skink (Eumeces fasciatus), and American toad (Bufo americanus americanus).

Vegetation survey - A one-day walk-through was conducted at which time all vascular plant species that could be identified were recorded. An additional survey was conducted with a professional plant ecologist to specifically identify rare plants. The ORNL forester also surveyed the site to evaluate trees for potential significance and marketability.

This habitat is characterized by an overstory of white oak (Quercus alba), scarlet oak (Quercus coccinea), southern red oak (Quercus falcata), tulip poplar (Liriodendron tulipifera), and pignut hickory (Carya glabra). There is also a scattering of chestnut oak (Quercus montana) and red maple (Acer rubrum) in the overstory in this area. The understory is relatively open and contains saplings of several different species, including American beech (Fagus grandifolia), black cherry (Prunus serotina), sourwood (Oxydendrum arboreum), sweetgum (Liquidambar styraciflua), and common pawpaw (Asimina triloba). Groundcover in the area is also scattered and includes Virginia creeper (Parthenocissus quinquefolia), Christmas fern (Polystichum acrostichoides), catbriar (Smilax sp.), poison ivy (Toxicodendron radicans), muscadine (Vitis rotundifolia), and striped pipsissewa (Chimaphila maculata).

In this dry upland forest, the prevalence of white oaks with exfoliating bark is notable. These trees provide potential roosting habitat for the federally endangered Indiana bat. Indiana bats use these trees for maternity roosts from approximately mid-May through mid-September (Harvey et. al.). Potential roost trees are depicted in Figure I.1. A complete plant list for this habitat is provided in Table I.2. 
Table I.2. Plant species list for the dry upland forest.

\begin{tabular}{ll}
\hline \multicolumn{1}{c}{ Scientific name } & \multicolumn{1}{c}{ Common name } \\
\hline Liriodendron tulipifera & Tulip poplar \\
Carya glabra & Pignut hickory \\
Nyssa sylvatica & Black gum \\
Quercus falcata & Southern red oak \\
Quercus coccinea & Scarlet oak \\
Quercus alba & White oak \\
Quercus montana & Chestnut oak \\
Acer rubrum & Red maple \\
Sassafras albidum & Sassafras \\
Fagus grandifolia & American beech \\
Prunus serotina & Black cherry \\
Asimina triloba & Common pawpaw \\
Vaccinium pallidum & Lowbush blueberry \\
Oxydendrum arboreum & Sourwood \\
Liquidambar styraciflua & Sweetgum \\
Juniperus virginiana & Eastern red cedar \\
Parthenocissus quinquefolia & Virginia creeper \\
Polystichum acrostichoides & Christmas fern \\
Smilax sp. & Catbriar \\
Toxicodendron radicans & Poison ivy \\
Vitis rotundifolia & Muscadine \\
Chimaphila maculata & Striped pipsissewa \\
Microstegium vimineum & Nepal grass \\
Lespedeza cuneata & Sericea lespedeza \\
Coronilla varia & Crown-vetch \\
Cirsium sp. & Thistle \\
Festuca sp. & Fescue \\
\hline &
\end{tabular}

\section{I.2.1.2 Moist Forest}

The moister forest is characterized by a northward facing slope that grades down into the Bear Creek watershed. Signs of overland flow in the direction of the watershed are noticeable in certain areas of this forest. This forest is bordered on the south by a sharp edge in certain locations and by a relatively gradual edge in other locations. Edges are characterized by grassy fields, scattered shrubs, and disturbed areas.

Bird survey results - A total of 14 bird species were identified in this habitat by either sight or song. Sign was noted for one additional species.

There was sign (tree drillings) noted for the federal- and state-listed yellow-bellied sapsucker. Five species were recorded at the site that are on the PIF list as being of regional importance in the ridge and valley. Interior forest species in this category that were noted in this habitat on and adjacent to the project site are the downy woodpecker, Acadian flycatcher (Empidonax virescens), yellow-throated vireo (Vireo flavifrons), and scarlet tanager (Piranga olivacea). Acadian flycatchers are particularly good indicators of moist forests. This flycatcher species has relatively specialized habitat requirements, being found in 
moist, predominantly deciduous woodlands. In most of the state, they are found along wooded streams and in moist ravines (Nicholson 1997). One other notable forest bird recorded on the site is the pileated woodpecker. A complete bird list for this habitat is provided in Table I.3.

Table I.3. Bird species list for the moist forest.

\begin{tabular}{|c|c|c|c|c|}
\hline \multirow{2}{*}{ Scientific name } & \multirow{2}{*}{ Common name } & \multicolumn{3}{|c|}{ Status } \\
\hline & & Federal & State & PIF \\
\hline \multicolumn{5}{|l|}{ Pigeons and doves } \\
\hline Zenaida macroura & Mourning dove & & & \\
\hline \multicolumn{5}{|l|}{ Woodpeckers } \\
\hline Sphyrapicus varius & Yellow-bellied sapsucker & MC & NM & \\
\hline Dryocopus pileatus & Pileated woodpecker & & & \\
\hline Melanerpes carolinus & Red-bellied woodpecker & & & \\
\hline Picoides pubescens & Downy woodpecker & & & RI \\
\hline \multicolumn{5}{|l|}{ Tyrant flycatchers } \\
\hline Empidonax virescens & Acadian flycatcher & & & RI \\
\hline \multicolumn{5}{|l|}{$\underline{\text { Swallows }}$} \\
\hline Hirundo rustica & Barn swallow & & & \\
\hline \multicolumn{5}{|l|}{ Titmice and chickadees } \\
\hline Poecile carolinensis & Carolina chickadee & & & RI \\
\hline Baeolophus bicolor & Tufted titmouse & & & \\
\hline \multicolumn{5}{|l|}{ Nuthatches } \\
\hline Sitta carolinensis & White-breasted nuthatch & & & \\
\hline \multicolumn{5}{|l|}{ Vireos } \\
\hline Vireo flavifrons & Yellow-throated vireo & & & RI \\
\hline Vireo olivaceus & Red-eyed vireo & & & \\
\hline \multicolumn{5}{|l|}{ Crows and jays } \\
\hline Corvus brachyrhynchos & American crow & & & \\
\hline \multicolumn{5}{|l|}{ Wood warblers } \\
\hline Vermivora pinus & Pine warbler & & & \\
\hline \multicolumn{5}{|l|}{ Tanagers } \\
\hline Piranga olivacea & Scarlet tanager & & & RI \\
\hline
\end{tabular}

Small mammal survey results - A total of 55 Sherman live traps were set out in the moist forest habitat. Small mammals were trapped for 7 nights during a 2-week period for a total of 385 trap nights ( 7 nights $\times$ 55 traps).

The white-footed mouse was by far the most common species captured in the small mammal traps in this habitat. Only two other species were trapped: the eastern chipmunk (Tamias striatus) and long-tailed weasel (Mustela frenata). Capturing a long-tailed weasel in a small mammal trap is highly unusual, and they are very difficult to capture at all, even when specifically targeted. Although seldom seen, the longtailed weasel is thought to be fairly common in Tennessee, especially in rural areas. They are active day or night and frequent a variety of habitats, including forest, meadows, and fields. They feed on a variety of small mammals, including mice (Reid 2006). As evidenced by trapping conducted on the SNS site, 
mouse populations in the area appear to be thriving, providing a reliable prey source for weasels. The location of the long-tailed weasel capture is shown on Figure I.2. Signs of coyote (scat) and white-tailed deer (scat and tracks) were also noted incidentally while conducting other surveys.

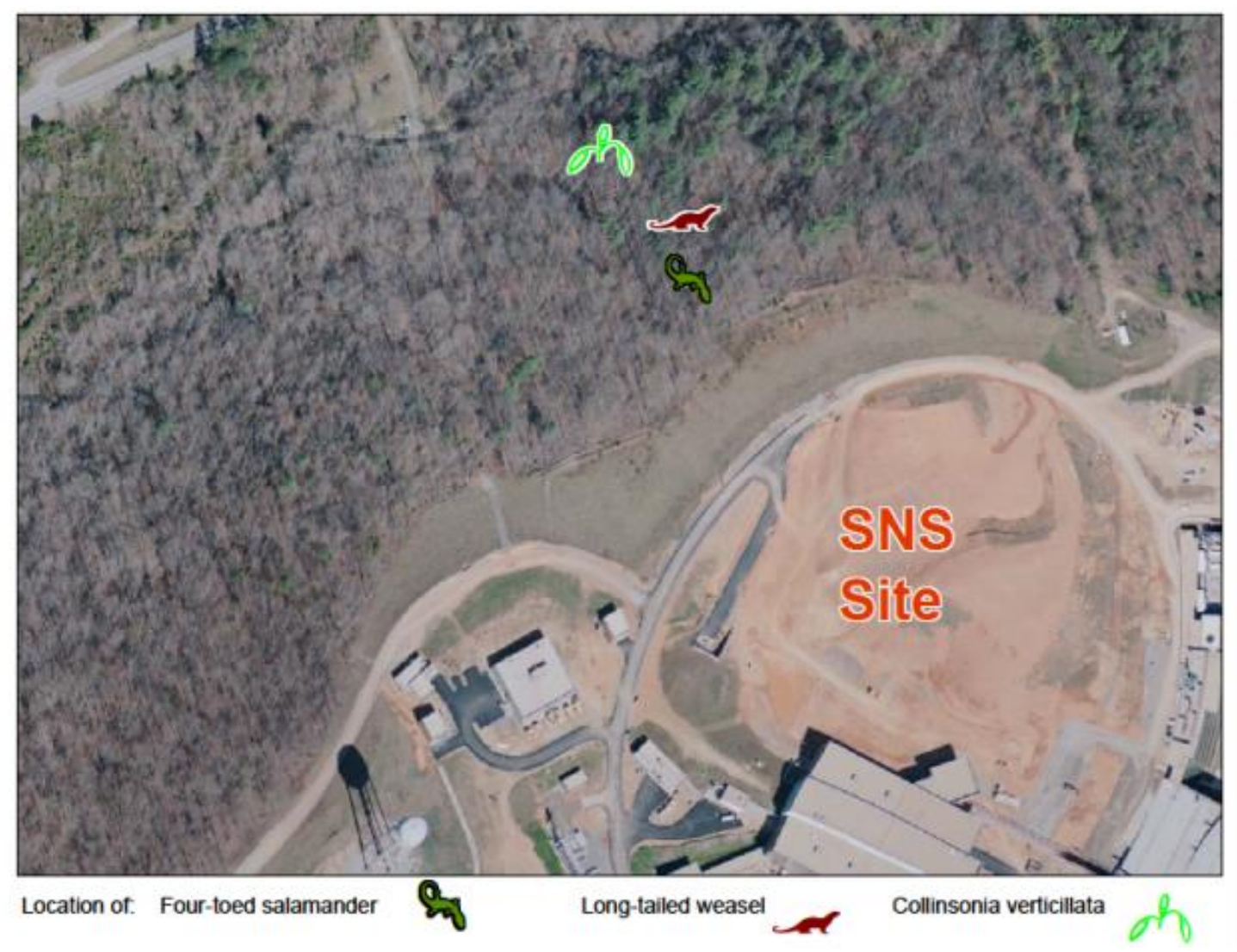

Figure I.2. Sensitive species locations.

Reptile and amphibian survey-A one-day VES was conducted on the site. This involved searching under logs, rocks, bark, leaf litter, and other debris. All reptiles and amphibians found were recorded. Incidental encounters with reptiles and amphibians were also recorded during surveys of other natural resources.

The majority of the reptiles and amphibians recorded for the site are considered to be common on the ORR. Species recorded included the eastern garter snake (Thamnophis sirtalis sirtalis), worm snake (Carphophis amoenus amoenus), northern ringneck snake (Diadophis punctatus edwardsii), northern slimy salamander (Plethodon glutinosus), long-tailed salamander (Eurycea longicauda longicauda) and four-toed salamander (Hemidactylium scutatum). The four-toed salamander has only been recorded on the ORR one other time (1996). This species is listed by the state of Tennessee as being "in need of management." This designation is given to any species or subspecies of nongame wildlife that the TWRA believes should be investigated to develop information relating to populations, distribution, habitat needs, limiting factors, and other biological and ecological data to determine management measures necessary for their continued ability to sustain themselves successfully. The four-toed salamander is normally associated with shallow pools of standing water, often in the vicinity of sphagnum and other mosses. They commonly nest adjacent to beaver ponds, seasonal pools, and streams. After the breeding season, they lead a fossorial existence in adjacent woodlands (Jensen, et. al. 2008). The breeding season for this species is September through December. The four-toed salamander found on the SNS site likely breeds downslope in the Bear Creek watershed wetlands, and traveled upslope during its nonbreeding season wanderings. There is no actual breeding habitat for this species on the proposed project site. The location 
at which the four-toed salamander was captured is depicted in Figure I.2. The capture of three species of salamanders on this site is evidence of the moister character of this area of the forest.

Vegetation survey-A one-day walk-through was conducted at which time all vascular plant species that could be identified were recorded. An additional survey was conducted with a professional plant ecologist to specifically identify rare plants. The ORNL forester also surveyed the site to evaluate trees for potential significance and marketability.

This area of the forest on the north side of the SNS facility is noticeably moister than the upland forested areas to the east. It is also a noticeably richer forest with more plant diversity. The overstory includes tulip poplar, pignut hickory, chestnut oak, southern red oak, white oak, sweetgum, scrub pine (Pinus virginiana) and white pine (Pinus strobus). A few very large chestnut oaks and white pines and one very large sweetgum are notable. The diverse understory includes black gum (Nyssa sylvatica), hemlock (Tsuga canadensis), sassafras (Sassafras albidum), American beech, flowering dogwood (Cornus florida), ironwood (Carpinus caroliniana), black cherry, sugar maple (Acer saccharum), redbud (Cercis canadensis), common pawpaw, umbrella magnolia (Magnolia tripetala), lowbush blueberry (Vaccinium pallidum), sourwood, sweetgum, Carolina buckthorn (Rhamnus caroliniana), yellow buckeye (Aesculus octandra) and devils-walkingstick (Aralia spinosa). Muscadine is also prevalent in the area.

The groundcover in this forest is extremely diverse, with the presence of a variety of ferns and herbaceous species. Ferns recorded in the area include Christmas fern, maidenhair fern (Adiantum pedatum), common grape fern (Botrychium dissectum), rattlesnake fern (Botrychium virginianum) and broad beech fern (Thelypteris hexagonoptera). Other groundcover plants in the area include striped pipsissewa, little brown jug (Hexastylis arifolia), prostrate tick-trefoil (Desmodium rotundifolium), downy rattlesnake plantain (Goodyera pubescens), false Solomon's-seal (Smilacina racemosa), lopseed (Phyrma leptostachya), wild yam (Dioscorea villosa), doll's eyes (Actaea pachypoda), black snakeroot (Sanicula odorata), Virginiasnakeroot (Aristolochia serpentaria), yellow passionflower (Passiflora lutea), tickseed (Coreopsis sp.), crested dwarf iris (Iris cristata), wood anemone (Anemone quinquefolia), may-apple (Podophyllum peltatum), yellow forest violet (Viola pubescens), and jack-in-the-pulpit (Arisaema triphyllum).

Of particular significance on this slope is the presence of whorled stoneroot (Collinsonia verticillata). Whorled stoneroot has a global rank of G3, as determined by NatureServe (nongovernmental organization of national, state, and provincial heritage programs). A rank of G3 means that the species is very rare and local throughout its range, or, because of other factors, vulnerable to extinction throughout its range.

Plants in this category generally have between 21 and 100 occurrences and fewer than 10,000 individuals. Although it has a global ranking, whorled stoneroot is not a listed plant in the state of Tennessee. The location of whorled stoneroot on the site is shown in Figure I.2.

Ginseng (Panax quinquefolius) was recorded on this same slope. Ginseng is listed as a special concern and commercially exploited (CE) species by the state of Tennessee. The state special concern status is given to plant species that are uncommon in Tennessee or have unique or highly specific habitat requirements or scientific value and, therefore, require careful monitoring of their status. The CE designation is given to plants being taken from the wild in large numbers and propagation or cultivation is insufficient to meet market demand. These plants are of long-term conservation concern. Ginseng is also ranked by the state Division of Natural Areas as an S3S4 species, meaning that it is rare to uncommon to widespread and secure in different areas of the state. NatureServe also gives it a G4 global ranking, meaning that it is globally secure. A complete plant list for this habitat is provided in Table I.4. 
Table I.4. Plant species list for the moist forest.

\begin{tabular}{|c|c|}
\hline Scientific name & Common name \\
\hline Lireodendron tulipifera & Tulip poplar \\
\hline Carya glabra & Pignut hickory \\
\hline Nyssa sylvatica & Black gum \\
\hline Quercus falcata & Southern red oak \\
\hline Quercus alba & White oak \\
\hline Quercus montana & Chestnut oak \\
\hline Pinus virginiana & Scrub pine \\
\hline Pinus strobus & White pine \\
\hline Acer rubrum & Red maple \\
\hline Tsuga canadensis & Hemlock \\
\hline Aesculus octandra & Yellow buckeye \\
\hline Sassafras albidum & Sassafras \\
\hline Fagus grandifolia & American beech \\
\hline Cornus florida & Flowering dogwood \\
\hline Carpinus caroliniana & Ironwood \\
\hline Prunus serotina & Black cherry \\
\hline Acer saccharum & Sugar maple \\
\hline Ilex opaca & American holly \\
\hline Cercis canadensis & Redbud \\
\hline Asimina triloba & Common pawpaw \\
\hline Magnolia tripetala & Umbrella magnolia \\
\hline Vaccinium pallidum & Lowbush blueberry \\
\hline Oxydendrum arboretum & Sourwood \\
\hline Liquidambar styraciflua & Sweetgum \\
\hline Rhamnus caroliniana & Carolina buckthorn \\
\hline Aralia spinosa & Devil's walkingstick \\
\hline Lonicera japonica & Japanese honeysuckle \\
\hline Lonicera maackii & Bush honeysuckle \\
\hline Morus sp. & Mulberry \\
\hline Euonymus & Euonymus \\
\hline Rhus copallina & Winged sumac \\
\hline Rhus glabra & Smooth sumac \\
\hline Rubus sp. & Blackberry \\
\hline Parthenocissus quinquefolia & Virginia creeper \\
\hline Polystichum acrostichoides & Christmas fern \\
\hline Adiantum pedatum & Maidenhair fern \\
\hline Botrychium dissectum & Common grape fern \\
\hline Thelypteris hexagonoptera & Broad beech fern \\
\hline Botrychium virginianum & Rattlesnake fern \\
\hline Panax quinuefolius & Ginseng \\
\hline Smilax sp. & Catbriar \\
\hline Toxicodendron radicans & Poison ivy \\
\hline
\end{tabular}


Table I.4. Plant species list for the moist forest (continued).

\begin{tabular}{ll}
\hline Scientific name & Common name \\
\hline Bignonia capreolata & Cross-vine \\
Vitis rotundifolia & Muscadine \\
Chimaphila maculata & Striped pipsissewa \\
Pycnanthemum pilosum & Mountain-mint \\
Microstegium vimineum & Nepal grass \\
Hexastylis arifolia & Little brown jug \\
Desmodium rotundifolium & Prostrate tick-trefoil \\
Desmodium nudiflorum & Naked-flowered tick-trefoil \\
Goodyera pubescens & Downy rattlesnake plantain \\
Smilacina racemosa & False Solomon's seal \\
Phryma leptostachya & Lopseed \\
Dioscorea villosa & Wild yam \\
Actaea pachypoda & Doll's eyes \\
Sanicula odorata & Black snakeroot \\
Aristolochia serpentaria & Virginia-snakeroot \\
Passiflora lutea & Yellow passion flower \\
Coreopsis sp. & Tickseed \\
Viola pubescens & Yellow forest violet \\
Arisaema triphyllum & Jack-in-the-pulpit \\
Iris cristata & Crested dwarf iris \\
Anemone quinquefolia & Wood anemone \\
Podophyllum peltatum & May-apple \\
Collinsonia verticillata & Whorled stoneroot \\
\hline
\end{tabular}

\section{I.2.1.3 Fields and Disturbed Areas}

This habitat that borders the forested areas includes steeply sloping areas characterized by grassy fields, scattered shrubs, and disturbed areas.

Bird survey results - A total of six bird species were identified in this habitat by either sight or song. One additional species, the wild turkey, was identified by signs (i.e., tracks).

Two species were recorded at the site that are on the PIF list as being of regional importance in the ridge and valley. Species in this category that were noted in this habitat were the indigo bunting (Passerina cyanea) and eastern towhee (Pipilo erythrophthalmus). A complete bird list for the fields and disturbed areas is provided in Table I.5.

Table I.5. Bird species list for fields and disturbed areas.

\begin{tabular}{llll}
\hline \multicolumn{1}{c}{ Scientific name } & \multirow{2}{*}{ Common name } & \multicolumn{3}{c}{ Status } \\
\cline { 3 - 4 } & & Federal & State \\
\hline $\begin{array}{l}\text { Pheasants and turkeys } \\
\text { Meleagris gallopavo }\end{array}$ & Wild turkey & & \\
Towhees, sparrows, and allies & & & \\
\hline
\end{tabular}




\begin{tabular}{|c|c|c|c|c|}
\hline \multirow{2}{*}{ Scientific name } & \multirow{2}{*}{ Common name } & \multicolumn{3}{|c|}{ Status } \\
\hline & & Federal & State & PIF \\
\hline Melospiza melodia & Song sparrow & & & \\
\hline \multicolumn{5}{|l|}{ Finches } \\
\hline Pipilo erythrophthalmus & Eastern towhee & & & RI \\
\hline Carduelis tristis & American goldfinch & & & \\
\hline \multicolumn{5}{|c|}{ Cardinals, grosbeaks, and allies } \\
\hline Passerina cyanea & Indigo bunting & & & RI \\
\hline Cardinalis cardinalis & Northern cardinal & & & \\
\hline Passerina caerulea & Blue grosbeak & & & \\
\hline
\end{tabular}

$\mathrm{RI}=$ regional importance

Small mammal survey results - A total of 40 Sherman live traps were set out in the fields and disturbed areas. Small mammals were trapped for 7 nights during a 2-week period for a total of 280 trap nights (7 nights $\times 40$ traps).

Hispid cotton rats (Sigmodon hispidis) were captured in large numbers in this habitat. The only other species captured in this habitat was the white-footed mouse. Raccoon (Procyon lotor) sign (tracks) was also noted incidentally.

Reptile and amphibian survey-A one-day VES was conducted in this habitat. No reptile or amphibian species were noted in this habitat during the survey.

Vegetation survey - A one-day walk-through was conducted at which time all vascular plant species that could be identified were recorded. An additional survey was conducted with a professional plant ecologist to specifically identify rare plants. The ORNL forester also surveyed the site to evaluate trees for potential significance and marketability.

The majority of this habitat is characterized by fescue (Festuca sp.), with a few other herbaceous species and scattered shrubs. Other herbaceous species noted included Sericea lespedeza (Lespedeza cuneata), Korean lespedeza (Kummerowia stipulacea), crown vetch (Coronilla varia), thistle (Cirsium sp.), Canada goldenrod (Solidago canadensis), Queen Anne's lace (Daucus carota), aster (Aster sp.), and big bluestem (Andropogon gerardii). Scattered shrubs in this habitat included autumn olive (Elaeagnus umbellate), smooth sumac (Rhus glabra), winged sumac (Rhus copallina), sycamore (Platanus occidentalis), tulip poplar, boxelder (Acer negundo), redbud, and blackberry (Rubus sp.). A small area of cattails (Typha latifolia) and willows (Salix sp.) is present around the northern recharge basin. A complete plant list for this habitat is provided in Table I.6.

Table I.6. Plant species list for fields and disturbed areas.

\begin{tabular}{ll}
\hline \multicolumn{1}{c}{ Scientific name } & \multicolumn{1}{c}{ Common name } \\
\hline Cercis canadensis & Redbud \\
Elaeagnus umbellata & Autumn olive \\
Rubus sp. & Blackberry \\
Platanus occidentalis & Sycamore \\
Salix sp. & Willow \\
\hline
\end{tabular}




\begin{tabular}{ll}
\hline Lireodendron tulipifera & Tulip poplar \\
Acer negundo & Boxelder \\
Rhus copallina & Winged sumac \\
Rhus glabra & Smooth sumac \\
Typha latifolia & Wideleaf cattail \\
Cirsium sp. & Thistle \\
Aster sp. & Aster \\
Daucus carota & Queen Anne's lace \\
Solidago canadensis & Canada goldenrod \\
Lespedeza cuneata & Sericea lespedeza \\
Kummerowia stipulacea & Korean lespedeza \\
Coronilla varia & Crown-vetch \\
Microstegium vimineum & Nepal grass \\
Andropogon gerardii & Big bluestem \\
Festuca sp. & Fescue \\
\hline
\end{tabular}

\section{I.2.1.4 Alternative \#2 Site Characteristics}

The Alternative \#2 site, located on the southwestern side of the SNS facility, is characterized by disturbed areas, a steeply sloping area of field habitat, other brushy areas, and a small wooded area. The wooded area is fragmented from the adjacent forest by roads and power-line corridors. Overland flow to an offsite settling pond is evident through the forested area, with the main flow coming through a culvert near the edge of the forest. A network of silt fencing is present downstream of the culvert. Deep gullies have been carved through the forest from runoff.

Bird survey results - A total of five bird species were identified in this habitat by either sight or song. All species sighted except for one are common species found in fields or along forest edges. The one forest species sighted was the ruby-throated hummingbird (Archilochus colubris).

One species recorded at the site, field sparrow (Spizella pusilla), is on the PIF list as being of regional importance in the ridge and valley. Table I.7 provides a list of bird species recorded on the site. 
Table I.7. Bird species list for Alternative \#2 habitats.

\begin{tabular}{lllll}
\hline \multicolumn{1}{c}{ Scientific name } & Common name & Status & \\
\cline { 3 - 4 } $\begin{array}{l}\text { Hummingbirds } \\
\text { Archilochus colubris }\end{array}$ & Ruby-throated hummingbird & & State & \\
Wrens & & & \\
$\begin{array}{l}\text { Thryothorus ludovicianus } \\
\text { Thrushes }\end{array}$ & Carolina wren & & \\
Sialia sialis & Eastern bluebird & & \\
Towhees, sparrows, and allies & & & \\
Spizella pusilla & Field sparrow & & \\
Finches & & & \\
Carduelis tristis & American goldfinch & & \\
\hline
\end{tabular}

$\mathrm{RI}=$ regional importance

Small mammal survey results - A total of 25 Sherman live traps were set out at the Alternative \#2 site. Small mammals were trapped for 7 nights during a 2-week period for a total of 175 trap nights (7 nights $\times$ 25 traps).

The hispid cotton rat was the only species captured in the fields at this site. White-footed mice and chipmunks were captured in the forested area.

Reptile and amphibian survey - A one-day VES was conducted in this habitat. The only species identified on the site was the pickerel frog (Rana palustris), which was seen adjacent to the culvert. One snake was seen, but it escaped before it could be identified.

Vegetation survey-A one-day walk-through was conducted at which time all vascular plant species that could be identified were recorded. An additional survey was conducted with a professional plant ecologist to specifically identify rare plants. The ORNL forester also surveyed the site to evaluate trees for potential significance and marketability.

The majority of the field habitat is characterized by fescue and Sericea lespedeza, with a few other herbaceous species and scattered shrubs. Other herbaceous species noted include the thistle, Canada goldenrod, yarrow (Achillea millefolium), aster (Aster sp.), rose pink (Sabatia angularis), and Joe-Pye weed (Eupatorium fistulosum). Scattered shrubs in this habitat include winged sumac, redbud, and blackberry.

The overstory in the wooded area includes mockernut hickory (Carya tomentosa), scrub pine, tulip poplar, red maple, southern red oak, and black gum. The understory includes sourwood, sassafras, sweetgum, American beech, southern red oak, white oak, flowering dogwood, black cherry, deerberry (Vaccinium stamineum), and common privet (Ligustrum vulgare). Muscadine is also prevalent in this area. Groundcover species include Christmas fern, striped pipsissewa, little brown jug, prostrate ticktrefoil, naked-flowered tick-trefoil (Desmodium nudiflorum), downy rattlesnake plantain, heal-all (Prunella vulgaris), and false Solomon's seal. Orange jewelweed (Impatiens capensis) is also prevalent in the washes. A complete plant list for this habitat is provided in Table I.8. 
Table I.8. Plant species list for Alternative \#2 habitats.

\begin{tabular}{|c|c|}
\hline Scientific name & Common name \\
\hline Lireodendron tulipifera & Tulip poplar \\
\hline Carya tomentosa & Mockernut hickory \\
\hline Nyssa sylvatica & Black gum \\
\hline Quercus falcata & Southern red oak \\
\hline Quercus alba & White oak \\
\hline Quercus montana & Chestnut oak \\
\hline Pinus virginiana & Scrub pine \\
\hline Acer rubrum & Red maple \\
\hline Fagus grandifolia & American beech \\
\hline Cornus florida & Flowering dogwood \\
\hline Prunus serotina & Black cherry \\
\hline Cercis Canadensis & Redbud \\
\hline Oxydendrum arboretum & Sourwood \\
\hline Vaccinium stamineum & Deerberry \\
\hline Lonicera japonica & Japanese honeysuckle \\
\hline Rhus copallina & Winged sumac \\
\hline Rhus glabra & Smooth sumac \\
\hline Ligustrum vulgare & Common privet \\
\hline Rubus sp. & Blackberry \\
\hline Polystichum acrostichoides & Christmas fern \\
\hline Toxicodendron radicans & Poison ivy \\
\hline Vitis rotundifolia & Muscadine \\
\hline Hexastylis arifolia & Little brown jug \\
\hline Desmodium rotundifolium & Prostrate tick-trefoil \\
\hline Desmodium nudiflorum & Naked-flowered tick-foil \\
\hline Goodyera pubescens & Downy rattlesnake plantain \\
\hline Chimaphila maculatA & Striped pipsissewa \\
\hline Prunella vulgaris & Heal-all \\
\hline Smilacina racemosa & False Solomon's seal \\
\hline Elephantopus & Elephant's foot \\
\hline Impatiens capensis & Orange jewelweed \\
\hline Cirsium sp. & Thistle \\
\hline Aster $s p$ & Aster \\
\hline Lespedeza sp. & Clover \\
\hline Solidago canadensis & Canada goldenrod \\
\hline Achillea millefolium & Yarrow \\
\hline Sabatia angularis & Rose-pink \\
\hline Eupatorium fistulosum & Joe-Pye weed \\
\hline Lespedeza cuneata & Sericea lespedeza \\
\hline Microstegium vimineum & Nepal grass \\
\hline Festuca sp. & Fescue \\
\hline
\end{tabular}




\section{APPENDIX II. ADDITIONAL DETAILS FROM 2013 FOREST INVENTORY}

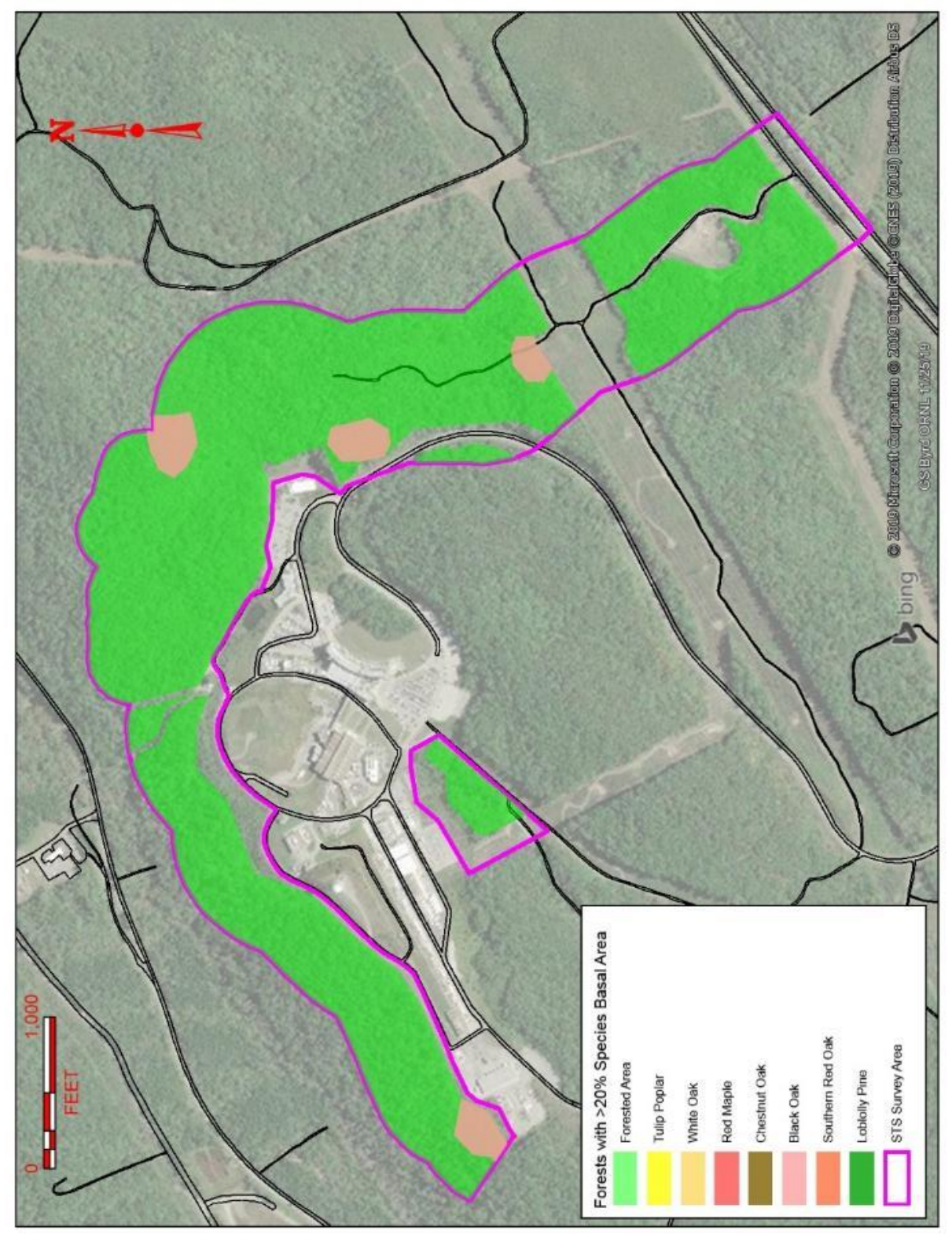




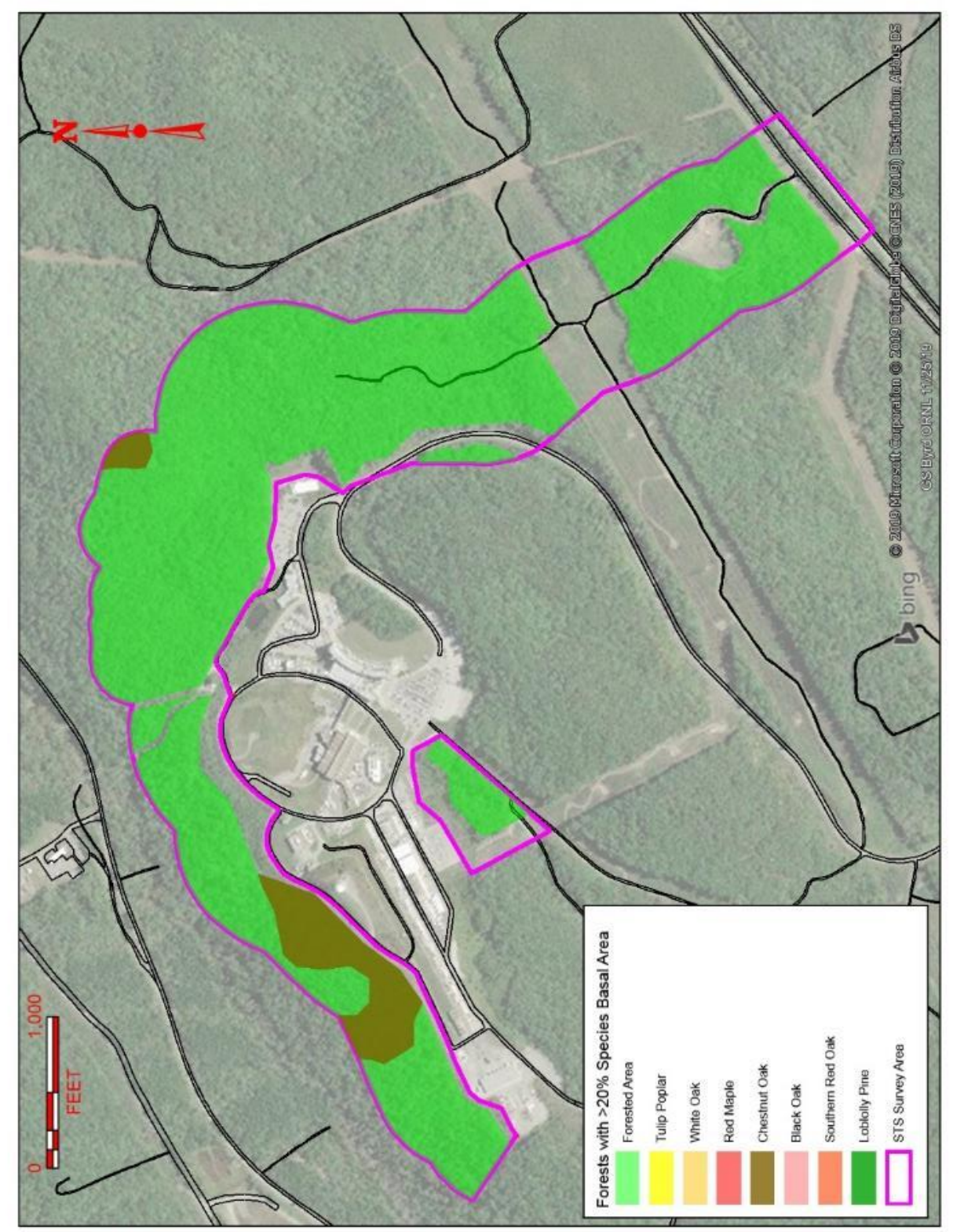




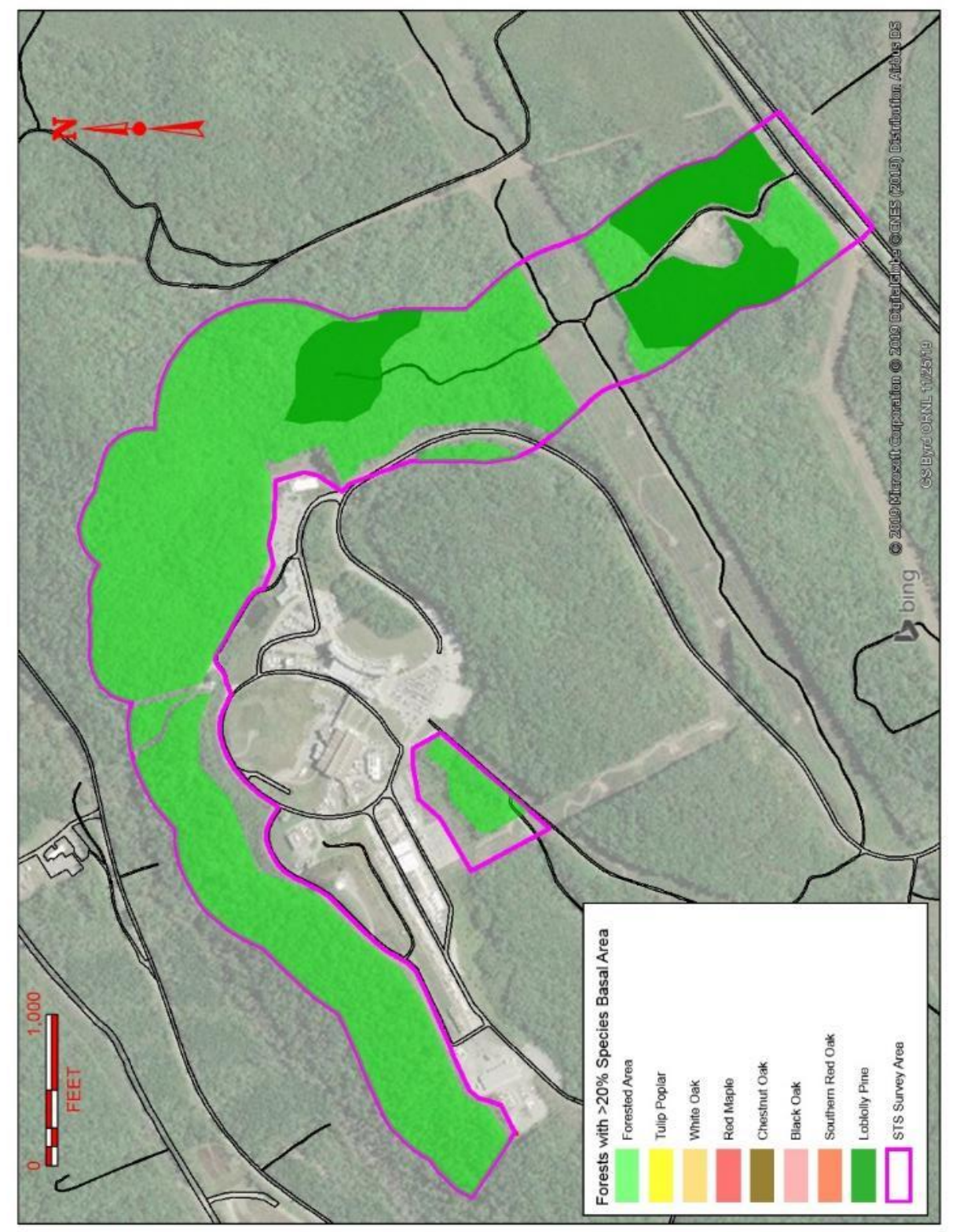




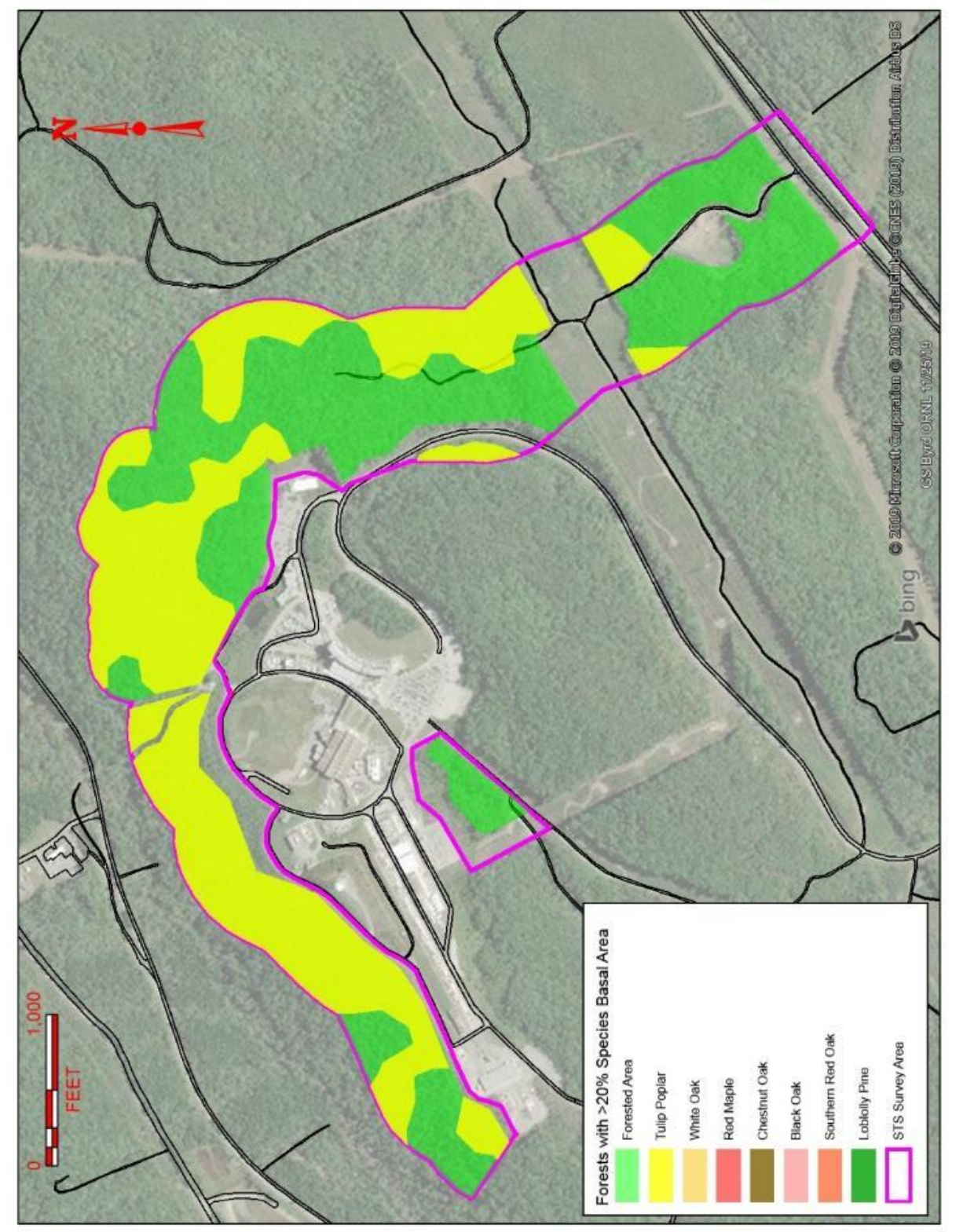




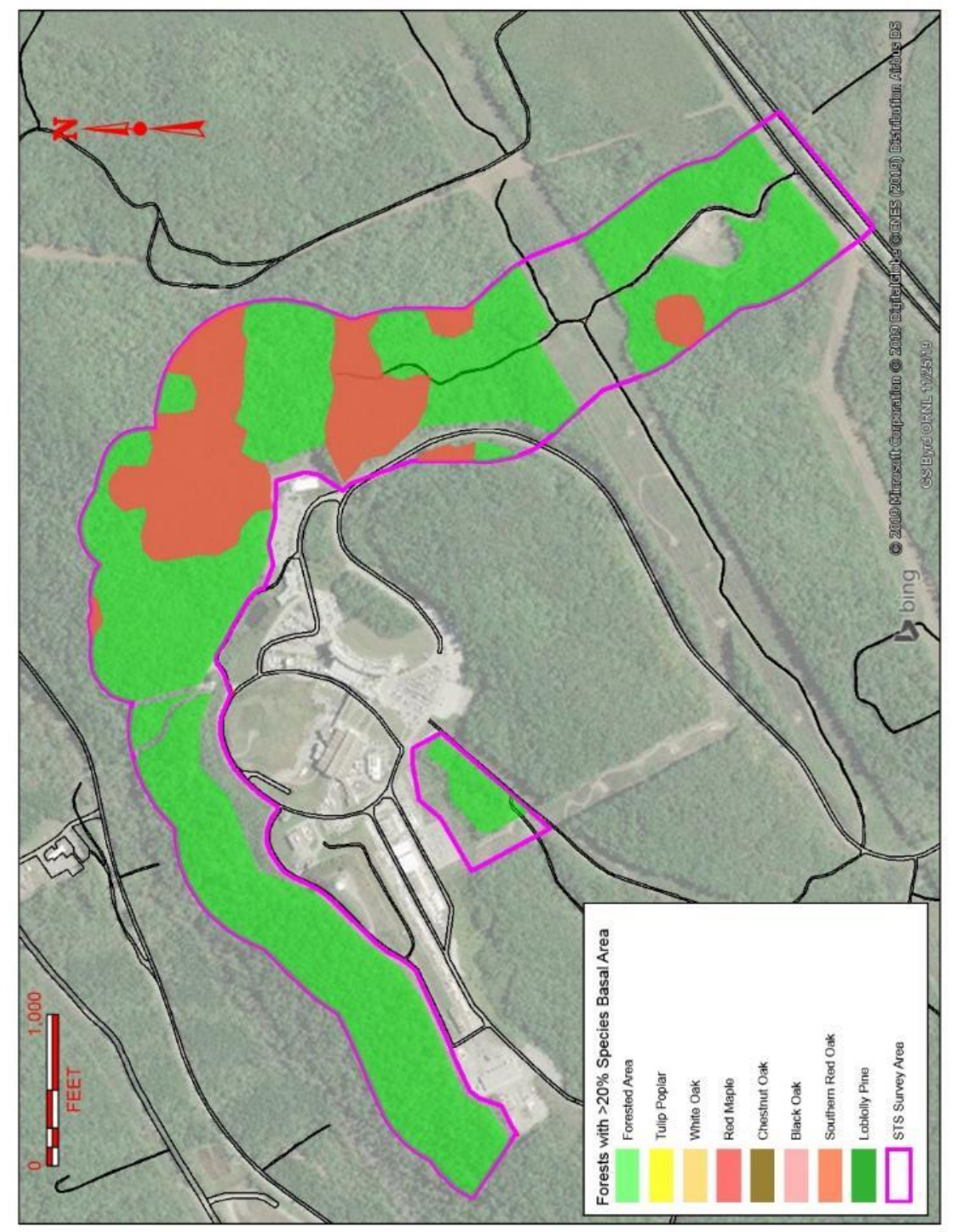




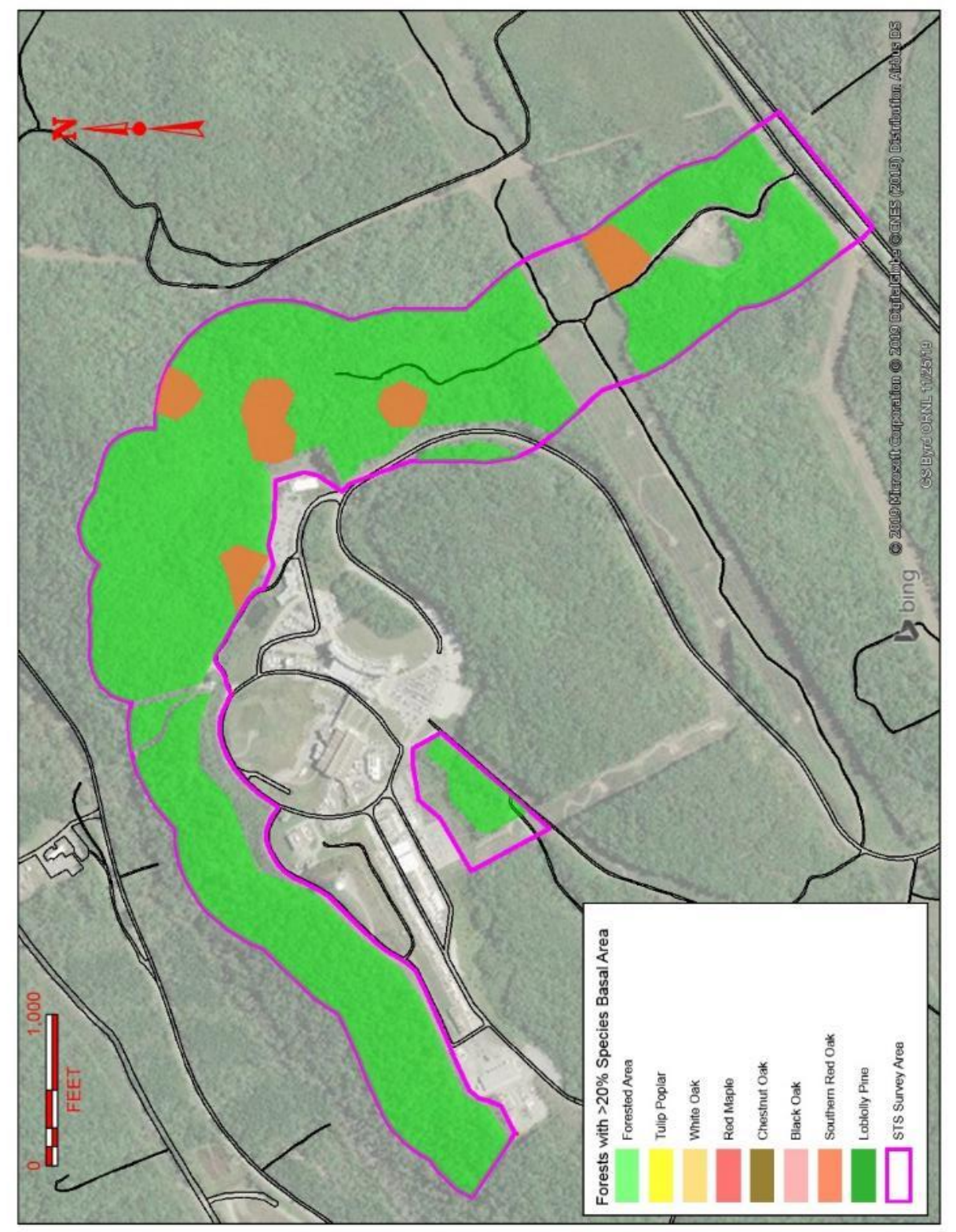




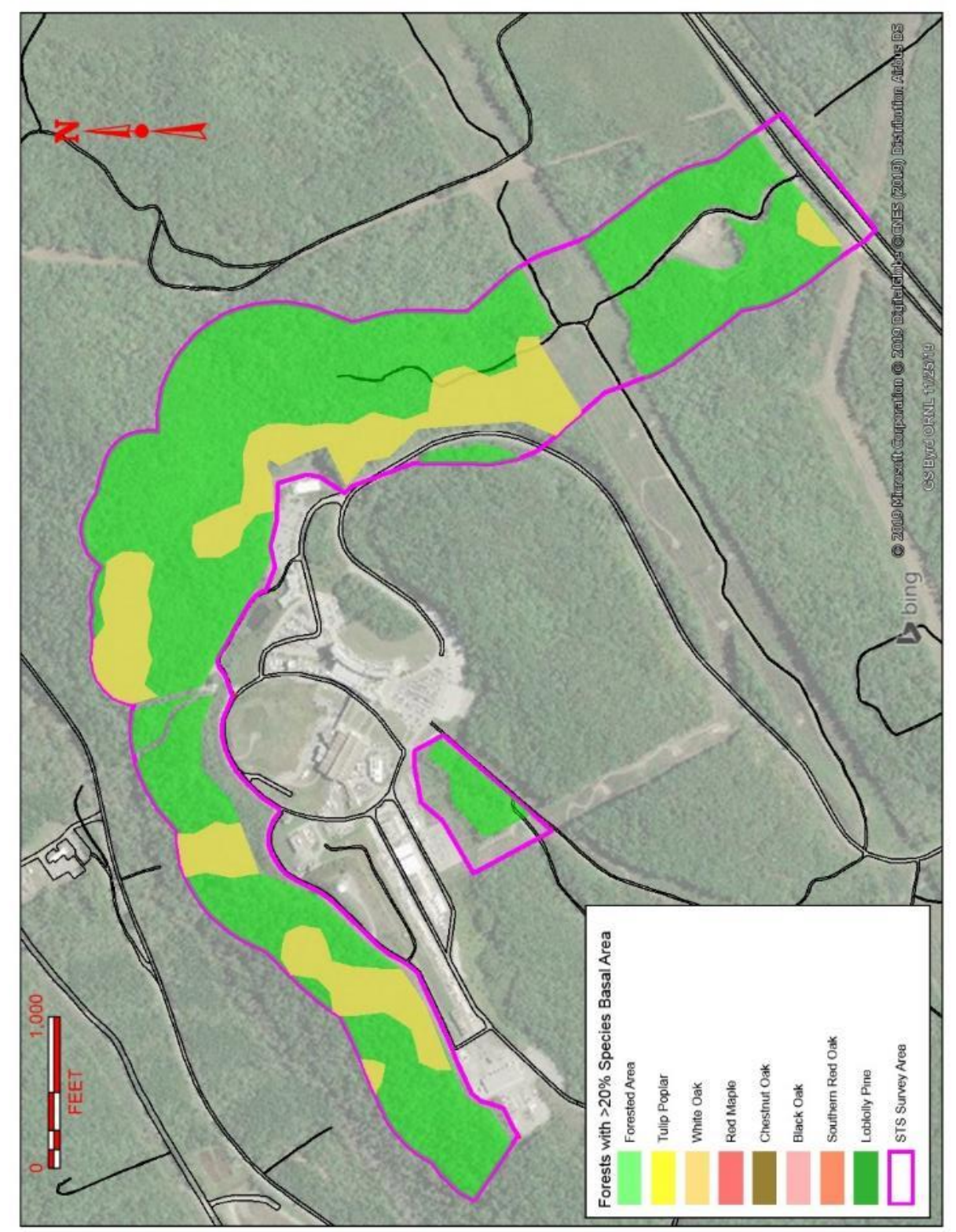


Largest diameter of live trees by species and number of trees tallied with diameter at breast height (dbh) greater than 30.0 in.

\begin{tabular}{|c|c|c|c|}
\hline Species & Common name & $\begin{array}{l}\text { Largest dbh } \\
\text { recorded (in.) }\end{array}$ & $\begin{array}{c}\text { Number of trees with } \\
\text { dbh }>30.0 \text { in. }\end{array}$ \\
\hline Acer rubrum & Red maple & 24.3 & \\
\hline Acer saccharum & Sugar maple & 33.4 & 1 \\
\hline Aralia spinosa & Devil's walking stick & 2.8 & \\
\hline Carya cordiformis & Bitternut hickory & 17.7 & \\
\hline Carya glabra & Pignut hickory & 28.3 & \\
\hline Carya tomentosa & Mockernut hickory & 23.8 & \\
\hline Celtis occidentalis & Hackberry & 16.2 & \\
\hline Cercis canadensis & Eastern redbud & 9 & \\
\hline Cornus florida & Flowering dogwood & 6.3 & \\
\hline Fagus grandifolia & American beech & 22.7 & \\
\hline Fraxinus americana & White ash & 11.5 & \\
\hline Juglans nigra & Black walnut & 32.5 & 1 \\
\hline Juniperus virginiana & Eastern redcedar & 23.5 & \\
\hline Liquidambar styraciflua & Sweetgum & 23.2 & \\
\hline Liriodendron tulipifera & Tulip poplar & 31.6 & 1 \\
\hline Morus rubra & Red mulberry & 16.8 & \\
\hline Nyssa sylvatica & Black gum & 14.5 & \\
\hline Oxydendron arboreum & Sourwood & 18 & \\
\hline Paulownia tomentosa & Princess tree & 11.4 & \\
\hline Pinus echinata & Shortleaf pine & 17.4 & \\
\hline Pinus strobus & White pine & 35.5 & 4 \\
\hline Pinus taeda & Loblolly pine & 18 & \\
\hline Pinus virginiana & Virginia pine & 18.3 & \\
\hline Plantanus occidentalis & American sycamore & 23.9 & \\
\hline Prunus serotina & Black cherry & 26 & \\
\hline Pyrus calleryana & Callery pear & 3.1 & \\
\hline Quercus alba & White oak & 34.1 & 3 \\
\hline Quercus coccinea & Scarlet oak & 22.5 & \\
\hline Quercus falcata & Southern red oak & 27.3 & \\
\hline Quercus montana & Chestnut oak & 41.1 & 2 \\
\hline Quercus rubra & Northern red oak & 35.6 & 2 \\
\hline Quercus stellata & Post oak & 21 & \\
\hline Quercus velutina & Black oak & 29.0 & \\
\hline Sassafras albidum & Sassafras & 10.8 & \\
\hline Ulmus alata & Winged elm & 12.9 & \\
\hline \multirow[t]{2}{*}{ Ulmus rubra } & Slippery elm & 10.3 & \\
\hline & & Total $\geq 30.0$ in. & 14 \\
\hline
\end{tabular}




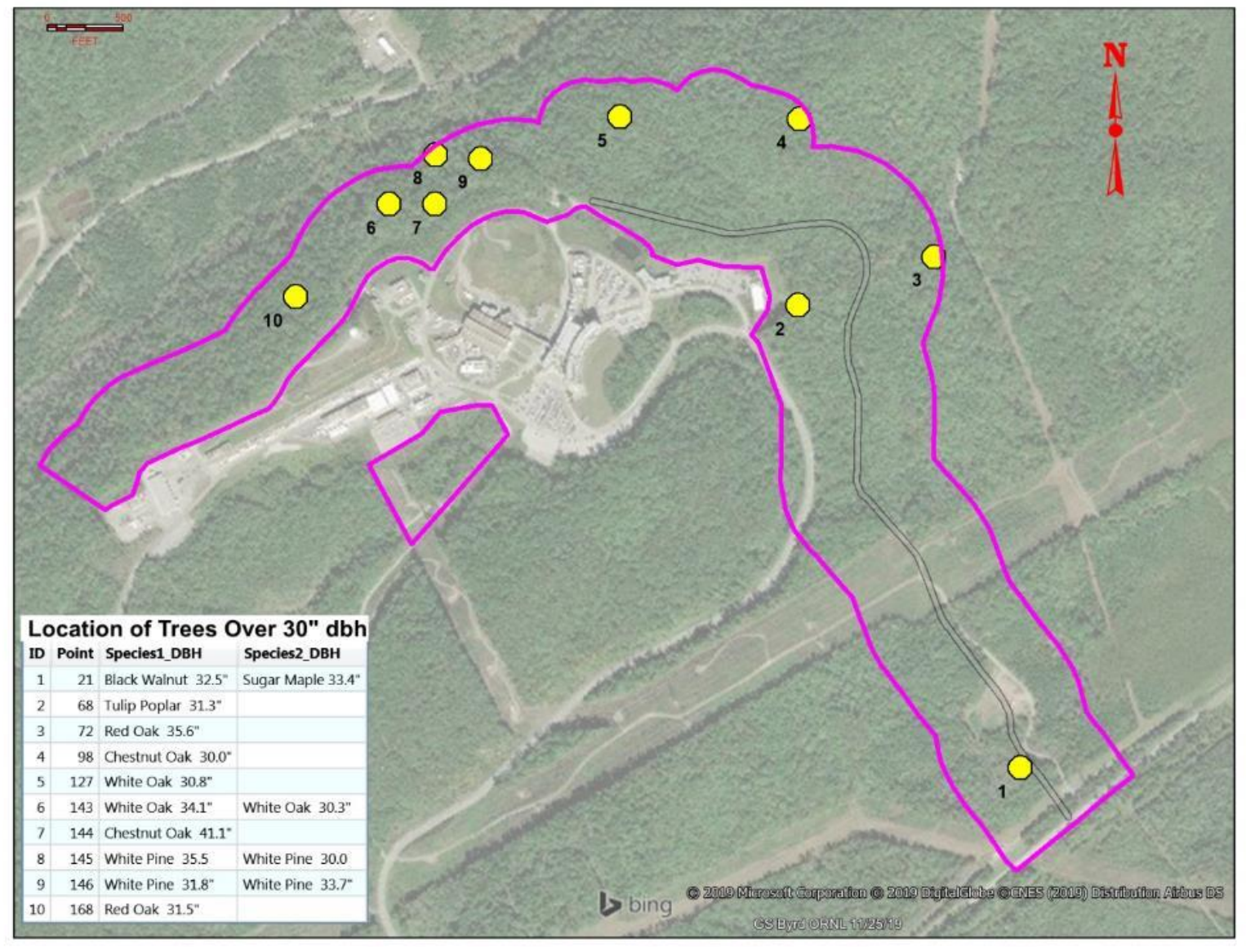




\section{APPENDIX III. COMPLETE LIST OF VERTEBRATE SPECIES DOCUMENTED WITHIN THE SNS STS PROJECT AREA}

\begin{tabular}{|c|c|c|c|c|c|c|}
\hline Type & Scientific name & Common name & Global rank & State rank & Federal status & State status \\
\hline Amphibian & Ambystoma maculatum & Spotted salamander & & & & \\
\hline Amphibian & Anaxyrus americanus & American toad & & & & \\
\hline Amphibian & Eurycea bislineata/wilderae & Two-lined salamander & & & & \\
\hline Amphibian & Gastrophryne carolinensis & Eastern narrow-mouthed toad & & & & \\
\hline Amphibian & Hemidactylium scutatum & Four-toed salamander & G5 & S3 & & $\mathrm{D}$ \\
\hline Amphibian & Hyla chrysoscelis & Cope's gray treefrog & & & & \\
\hline Amphibian & Lithobates catesbeianus & American bullfrog & & & & \\
\hline Amphibian & Lithobates clamitans & Green frog & & & & \\
\hline Amphibian & Lithobates palustris & Pickerel frog & & & & \\
\hline Amphibian & Notphthalmus viridescens & Eastern newt & & & & \\
\hline Amphibian & Plethodon glutinosis & Slimy salamander & & & & \\
\hline Amphibian & Pseudacris crucifer & Spring peeper & & & & \\
\hline Bat & Corynorhinus rafinesquii & Rafinesque's big-eared bat & G3G4 & S3 & & $\mathrm{D}$ \\
\hline Bat & Eptesicus fuscus & Big brown bat & & & & \\
\hline Bat & Lasionycteris noctivagans & Silver-haired bat & & & & \\
\hline Bat & Lasiurus borealis & Eastern red bat & & & & \\
\hline Bat & Lasiurus cinereus & Hoary bat & & & & \\
\hline Bat & Lasiurus seminolus & Seminole bat & & & & \\
\hline Bat & Myotis grisescens & Gray bat & G4 & $\mathrm{S} 2$ & $\mathrm{E}$ & E \\
\hline Bat & Myotis leibii & Eastern small-footed bat & G4 & S2S3 & & $\mathrm{D}$ \\
\hline Bird & Myotis septentrionalis & Northern long-eared bat & G1G2 & S1S2 & $\mathrm{T}$ & $\mathrm{T}$ \\
\hline Bat & Myotis lucifugus & Little brown bat & G3 & $\mathrm{S} 3$ & UR & $\mathrm{T}$ \\
\hline Bat & Myotis sodalis & Indiana bat & G2 & $\mathrm{S} 1$ & $\mathrm{E}$ & E \\
\hline Bat & Nycticeius humeralis & Evening bat & & & & \\
\hline Bat & Perimyotis subflavus & Tricolored bat & $\mathrm{G} 2 \mathrm{G} 3$ & $\mathrm{~S} 2 \mathrm{~S} 3$ & UR & $\mathrm{T}$ \\
\hline Bat & Tadarida brasiliensis & Brazilian free-tailed bat & & & & \\
\hline
\end{tabular}




\begin{tabular}{|c|c|c|c|c|c|c|}
\hline Type & Scientific name & Common name & Global rank & State rank & Federal status & State status \\
\hline Bird & Aix sponsa & Wood duck & & & & \\
\hline Bird & Archilochus colubris & Ruby-throated hummingbird & & & & \\
\hline Bird & Baeolophus bicolor & Tufted titmouse & & & & \\
\hline Bird & Buteo lineatus & Red-shouldered hawk & & & & \\
\hline Bird & Buteo jamaicensus & Red-tailed hawk & & & & \\
\hline Bird & Cathartes aura & Turkey vulture & & & & \\
\hline Bird & Coragyps atratus & Black vulture & & & & \\
\hline Bird & Cardinalis cardinalis & Northern cardinal & & & & \\
\hline Bird & Coccyzus americanus & Yellow-billed cuckoo & & & & \\
\hline Bird & Colaptes auratus & Northern flicker & & & & \\
\hline Bird & Contopus virens & Eastern wood-pewee & & & & \\
\hline Bird & Catharus ustslatus & Swainson's thrush & & & & \\
\hline Bird & Tachycineta bicolor & Tree swallow & & & & \\
\hline Bird & Setophaga discolor & Prairie warbler & & & & \\
\hline Bird & Corvus brachyrhynchos & American crow & & & & \\
\hline Bird & Turdus migratorius & American robin & & & & \\
\hline Bird & Cyanocitta cristata & Blue jay & & & & \\
\hline Bird & Dryocopus pileatus & Pileated woodpecker & & & & \\
\hline Bird & Empidonax virescens & Acadian flycatcher & & & & \\
\hline Bird & Hirundo rustica & Barn swallow & & & & \\
\hline Bird & Molothrus ater & Brown-headed cowbird & & & & \\
\hline Bird & Setophaga americana & Northern parula & & & & \\
\hline Bird & Polioptila caerulea & Blue-gray gnatcatcher & & & & \\
\hline Bird & Haemorhous mexicanus & House finch & & & & \\
\hline Bird & Melanerpes carolinus & Red-bellied woodpecker & & & & \\
\hline Bird & Melospiza melodia & Song sparrow & & & & \\
\hline Bird & Meteagris gallopava silvestris & Wild turkey & & & & \\
\hline Bird & Mimus polyglottos & Northern mockingbird & & & & \\
\hline Bird & Quiscalus guiscula & Common grackle & & & & \\
\hline Bird & Passerculus sandwichensis & Savannah sparrow & G5 & $\mathrm{S} 1 \mathrm{~B}, \mathrm{~S} 4 \mathrm{~N}$ & & Rare \\
\hline Bird & Passerina caerulea & Blue grosbeak & & & & \\
\hline
\end{tabular}




\begin{tabular}{|c|c|c|c|c|c|c|}
\hline Type & Scientific name & Common name & Global rank & State rank & Federal status & State status \\
\hline Bird & Passerina cyanea & Indigo bunting & & & & \\
\hline Bird & Picoides pubescens & Downy woodpecker & & & & \\
\hline Bird & Pipilo erythrophthalmus & Eastern towhee & & & & \\
\hline Bird & Piranga olivacea & Scarlet tanager & & & & \\
\hline Bird & Piranga rubra & Summer tanager & & & & \\
\hline Bird & Poecile carolinensis & Carolina chickadee & & & & \\
\hline Bird & Sayornis phoebe & Eastern phoebe & & & & \\
\hline Bird & Setophaga citrina & Hooded warbler & & & & \\
\hline Bird & Setophaga pensylvanica & Chestnut-sided warbler & & & & \\
\hline Bird & Setophaga pinus & Pine warbler & & & & \\
\hline Bird & Geothylpis trichas & Common yellowthroat & & & & \\
\hline Bird & Sialia sialis & Eastern bluebird & & & & \\
\hline Bird & Sitta carolinensis & White-breasted nuthatch & & & & \\
\hline Bird & Sphyrapicus varius & Yellow-bellied sapsucker & & & & \\
\hline Bird & Spinus tristis & American goldfinch & & & & \\
\hline Bird & Spizella pusilla & Field sparrow & & & & \\
\hline Bird & Spizella passerina & Chipping sparrow & & & & \\
\hline Bird & Sturnella magna & Eastern meadowlark & & & & \\
\hline Bird & Sturnus vulgaris & European starling & & & & \\
\hline Bird & Thryothorus ludovicianus & Carolina wren & & & & \\
\hline Bird & Vireo flavifrons & Yellow-throated vireo & & & & \\
\hline Bird & Setophaga petechia & Yellow warbler & & & & \\
\hline Bird & Icteria virens & Yellow-breasted chat & & & & \\
\hline Bird & Buteo platypterus & Broad-winged hawk & & & & \\
\hline Bird & Agelaius phoeniceus & Red-winged blackbird & & & & \\
\hline Bird & Vireo olivaceus & Red-eyed vireo & & & & \\
\hline Bird & Vireo griseus & White-eyed vireo & & & & \\
\hline Bird & Vireo flavifrons & Yellow-throated vireo & & & & \\
\hline Bird & Zenaida macroura & Mourning dove & & & & \\
\hline Bird & Zonotrichia albicollis & White-throated sparrow & & & & \\
\hline Mammal & Blarina brevicauda & Short-tailed shrew & & & & \\
\hline
\end{tabular}




\begin{tabular}{|c|c|c|c|c|c|c|}
\hline Type & Scientific name & Common name & Global rank & State rank & Federal status & State status \\
\hline Mammal & Canis latrans & Coyote & & & & \\
\hline Mammal & Mustela frenata & Long-tail weasel & & & & \\
\hline Mammal & Odocoileus virginianus & Deer & & & & \\
\hline Mammal & Peromyscus leucopus & White-footed mouse & & & & \\
\hline Mammal & Peromyscus sp & Peromyscus & & & & \\
\hline Mammal & Procyon lotor & Raccoon & & & & \\
\hline Mammal & Sigmodon hispidus & Cotton rat & & & & \\
\hline Mammal & Synaptomys cooperi & Southern bog lemming & G5 & S4 & & $\mathrm{D}$ \\
\hline Mammal & Tamias striatus & Eastern chipmunk & & & & \\
\hline Reptile & Agkistrodon contortrix & Copperhead & & & & \\
\hline Reptile & Carphophis amoenus & Wormsnake & & & & \\
\hline Reptile & Coluber constrictor & Racer & & & & \\
\hline Reptile & Diadophis punctatus & Ring-necked snake & & & & \\
\hline Reptile & Ophisaurus attenuatus & Eastern slender glass lizard & G5T5 & S3 & & $\mathrm{D}$ \\
\hline Reptile & Pantherophis guttatus & Corn Snake & & & & \\
\hline Reptile & Lampropeltis triangulum & Milksnake & & & & \\
\hline Reptile & Nerodia sipedon & Watersnake & & & & \\
\hline Reptile & Pantherophis spiloides & Rat snake & & & & \\
\hline Reptile & Scincella lateralis & Little brown skink & & & & \\
\hline Reptile & Plestiodon fasciatus & Five-lined skink & & & & \\
\hline Reptile & Terrapene carolina & Eastern box turtle & & & & \\
\hline Reptile & Thamnophis sirtalis & Gartersnake & & & & \\
\hline Reptile & Virginia valeriae & Earthsnake & & & & \\
\hline
\end{tabular}

